\title{
Sensitivity and Speed of Induced Defense of Cabbage (Brassica oleracea L.): Dynamics of BoLOX Expression Patterns During Insect and Pathogen Attack
}

\author{
Si-Jun Zheng, ${ }^{1}$ Jeroen P. van Dijk, ${ }^{2}$ Maaike Bruinsma, ${ }^{1}$ and Marcel Dicke ${ }^{1}$ \\ ${ }^{1}$ Laboratory of Entomology, Wageningen University, P.O. Box 8031, 6700 EH Wageningen, The Netherlands; ${ }^{2}$ RIKILT-Institute \\ of Food Safety, Wageningen University and Research Centre, P.O. Box 230, 6700 AE Wageningen, The Netherlands
}

Submitted 2 April 2007. Accepted 2 July 2007.

\begin{abstract}
The lipoxygenase pathway is involved in the early steps of plant responses to herbivorous insects and phytopathogens. Induced defenses in the crucifer Brassica oleracea have been well documented. Here, we have cloned a LIPOXYGENASE (LOX) from $B$. oleracea (BoLOX). The sequence reveals that the BoLOX protein has a transit peptide for chloroplast targeting, which is characteristic for class 2 LOXs involved in jasmonic acid (JA) biosynthesis which takes place in the chloroplast. Phylogenetic analysis shows that $B o L O X$ is closely related to $B$. napus $B n L O X 2 f l$ and Arabidopsis thaliana AtLOX2, which mediates JA biosynthesis. BoLOX also shares functional characteristics with AtLOX2; BoLOX is inducible by wounding, JA treatment, and herbivores such as caterpillars (Pieris rapae, $P$. brassicae, and Mamestra brassicae), spider mites (Tetranychus urticae), locusts (Schistocerca gregaria), and a bacterial pathogen (Pseudomonas syringae pv. tomato). Of these, Pieris spp. caterpillars also induce $A t L O X 2$ and JA biosynthesis in Arabidopsis. However, the aphid Myzus persicae did not induce $B o L O X$, which agrees with previous reports that this aphid induces neither AtLOX2 nor JA biosynthesis in Arabidopsis. Quantitative expression analysis of temporal, spatial, and density-dependent BoLOX transcript levels through real-time quantitative polymerase chain reaction demonstrated that $B o L O X$ is maximally expressed after feeding by only two first-instar caterpillars for $24 \mathrm{~h}$. Systemic expression was approximately 10-fold lower than local expression for herbivore-induced responses. The good correlation of $B o L O X$ transcript levels with reports in the literature on induced defenses of $B$. oleracea is discussed.
\end{abstract}

Plants serve as food to a wide variety of consumers. The most diverse and abundant group of herbivores consists of insects. In all, $45 \%$ of the approximately 1 million described insect species feed on plants (Schoonhoven et al. 2005). Plants have evolved a range of defenses to ward off this diversity of attackers (Kessler and Baldwin 2002; Schoonhoven et al. 2005; Walling 2000). These defenses can be classified as constitutive defenses that are present independent of attack and

Corresponding author: Marcel Dicke; Telephone: +31-317-484311; Fax: +31-317-484821; E-mail: marcel.dicke@wur.nl

Nucleotide sequence data for the BoLOX and GAPDH genes are available in the GenBank database under gene accession numbers EF123056 and EF123055, respectively. induced defenses that are induced by attack (Dicke et al. 2003; Karban and Baldwin 1997).

Induced defenses are mediated by signal transduction that links the damage with the changed phenotype. There are three main signal-transduction pathways that underlie induced defenses (i.e., the jasmonate, shikimate, and ethylene pathways) (Dicke and Van Poecke 2002; Kessler and Baldwin 2002). Of these pathways, the jasmonate pathway seems to play a dominant role in insect-induced, mite-induced, and wound-induced plant responses. For instance, jasmonates have been shown to be induced by Manduca sexta caterpillars in native tobacco plants (Kahl et al. 2000) or by Pieris rapae caterpillars in Arabidopsis (Reymond et al. 2004). A key enzyme in the biosynthetic pathway toward jasmonic acid (JA) is lipoxygenase (LOX) that uses linolenic acid as a substrate. The LOX gene has been shown to be induced in response to wounding or herbivory in plants such as Arabidopsis, native tobacco, and tomato (Bell et al. 1995; Halitschke and Baldwin 2003; Heitz et al. 1997). Disrupting LOX RNA accumulation results in a plant phenotype that is impaired in defense against herbivorous insects such as caterpillars (Kessler et al. 2004; Royo et al. 1999). AtLOX2 is induced by insect herbivory and Atlox 2 antisense plants are impaired in anti-insect defense (Bell et al. 1995; Van Poecke and Dicke 2002; Van Poecke et al. 2001).

After major developments in the knowledge of signal-transduction in induced defenses of Arabidopsis against pathogens (Pieterse and Van Loon 1999; Ryals et al. 1995), this model plant also has been incorporated in studies on induced plant defenses against herbivorous insects (Barth and Jander 2006; Jander et al. 2001; Reymond et al. 2000, 2004; Stotz et al. 2002; Van Poecke and Dicke, 2002, 2004; Wittstock et al. 2004). Arabidopsis provides a valuable model plant for ecologists to use to investigate mechanisms of induced defense through a molecular genetic approach because full-genome microarrays, extensive mutant collections, and ample information on signal transduction are available (Mauricio 1998; Mauricio and Rausher 1997; Mauricio et al. 1997; MitchellOlds 2001; Van Poecke and Dicke 2004). However, to investigate the effects of genes on community ecology, other crucifers are more suitable because, in nature, Arabidopsis has little interaction with herbivorous insects because they are active in a different time window. There is extensive information on the ecology of brassicaceous plants (Agrawal 2000; Gols et al. 2005; Harvey et al. 2003; Louda and Rodman 1996; Nielsen and de Jong 2005; Root 1973; Shiojiri et al. 2002; van Dam et al. 2004). Brassica spp. are attacked by species from very dif- 
ferent insect orders, including beetles, caterpillars, aphids, and thrips, and are pollinated by hymenopteran insects. The herbivorous insects are attacked by a range of carnivorous insects, including parasitic wasps and predatory insects. Characteristics of Brassica plants have been documented to affect insects up until the fourth trophic level (Harvey et al. 2003); consequently, the phenotype of Brassica plants can have profound effects on community processes. Brassica oleracea is commonly known as a cultivated plant, and agricultural varieties have been investigated intensively for induced defenses against insects (Mattiacci et al. 1995; Reymond et al. 2004; Shiojiri et al. 2002; Vuorinen et al. 2004). Yet, wild populations of this plant exist in Europe and provide interesting potential for ecological investigations (Moyes and Raybould 2001; Moyes et al. 2000).

At present, there are interesting options for using Arabidopsis as a stepping stone toward Brassica spp. in a molecular ecological research program. For instance, 70-mer oligomicroarrays based on the Arabidopsis genome can be used for transcriptomics in Brassica spp. and Arabidopsis sequence information can be used to clone related genes in other brassicaceous plants (Lee et al. 2004). Ecologists are interested in specificity of plant-attacker interactions and in quantitative data on temporal variation in responses of plants to their attackers. So far, transcriptomic analyses of plant-insect interactions have concentrated mostly on elucidating which genes are upregulated, but quantitative analyses have remained rare (Halitschke and Baldwin 2003; Park et al. 2002). However, the development of quantitative real-time polymerase chain reaction (PCR) allows careful quantitative analysis of gene expression patterns (Halitschke and Baldwin 2003; Halitschke et al. 2004). Such information will provide important new details on the temporal patterns of gene expression, and comparing these patterns among responses to different attackers will provide information on responses of plants to different community members. This is the topic of the present study.

We have cloned a $B$. oleracea $L O X$ gene that is inducible by wounding and insect herbivory. Through quantitative real-time PCR, we have investigated its transcript levels in response to feeding by four insect species of different orders, a mite species, mechanical wounding, JA application, and a pathogenic microorganism. Herbivore-density-related responses as well as temporal patterns in BoLOX transcript levels have been quantified for damaged as well as systemic leaves. The data show that transcript levels of this BoLOX gene are strongly upregulated in response to feeding damage by locusts, spider mites, and three species of caterpillars, including one generalist and two specialists, and in response to infection with the pathogenic bacterium Pseudomonas syringae. Maximum transcript levels (up to 10,000-fold compared with uninfested control leaves) in response to caterpillar feeding were reached after $24 \mathrm{~h}$ and, surprisingly, the maximum transcript level was little affected by the number of caterpillars that fed on the plant. Through quantitative real-time PCR, BoLOX RNAs already were detected $1 \mathrm{~h}$ after caterpillar feeding. This contrasted with the time $(24 \mathrm{~h})$ when BoLOX RNAs were first detected when conventional RT (reverse-transcription) PCR was used to record RNA accumulation. Mechanical damage and JA also induced accumulation of BoLOX RNA. In contrast to the relationship between herbivore density and BoLOX transcript levels, there was a linear relationship between JA dose and BoLOX transcript levels.

\section{RESULTS}

Isolation and characterization of $B o L O X$ CDNA.

A partial sequence $(1,021 \mathrm{bp})$ of the cabbage $L O X$ gene was obtained after sequencing fragments obtained by RT-PCR using degenerate oligonucleotide primers. A full-length cDNA of $2,785 \mathrm{bp}$ was isolated using rapid amplification of cDNA ends (5'-RACE and 3'-RACE). This cDNA clone contained an open reading frame starting with an ATG codon preceded by an inframe stop codon, indicating that it contains the complete coding region. The open reading frame of 2,676 nucleotides encoded a predicted protein of 891 amino acids. This cDNA clone was designated $B$. oleracea LOX gene (BoLOX). The deduced protein sequence of BoLOX showed high variability in the N-terminus and high similarity with other known LOX proteins in the C-terminus (Fig. 1).

The iPSORT protein-sorting program predicted subcellular localization of BoLOX in the cytoplasm and chloroplast because BoLOX contains a transit peptide for chloroplast and mitochondrial targeting. Similar to AtLOX2 (Bell and Mullet 1993), potato H1 (LOX2) and H3 (LOX3) (Royo et al. 1996), and tomato TomLOXC and TomLOXD (Heitz et al. 1997), the BoLOX sequence exhibits N-terminal extensions of approximately 60 residues, showing a chloroplast and mitochondrial transit peptide. The general features of transit peptides for chloroplast targeting include a high proportion of hydrophilic and small hydrophobic amino acid residues and a near lack of acidic residues. The Arabidopsis and tomato LOX enzymes have been demonstrated to be actively imported into chloroplasts (Bell et al. 1995; Heitz et al. 1997); also, potato H1 (LOX2) and H3 (LOX3) are localized within the chloroplasts (Farmaki et al. 2007). An important function of the chloroplast-localized class 2 LOXs is their involvement in catalyzing the oxygenation of free linolenic acid as the initial step in JA biosynthesis (Wasternack et al. 2006). Like other known plant LOX sequences (Peng et al. 1994), the BoLOX sequence exhibits the conserved amino acid sequence HAAVNFGQY present in the C-terminal part (Fig. 1). From the phylogenetic analysis (Fig. 2), it is clear that the nucleotide sequence of $B o L O X$ is very close to that from B. napus BnLOX2fl (Terp et al. 2006) and Arabidopsis thaliana AtLOX2 (Bell and Mullet 1993). BoLOX showed 87 and $75 \%$ amino acid sequence identity with $B$. napus BnLOX2fl and A. thaliana AtLOX2, respectively. Based on sequence identity with known 13-LOXs, the presence of LOX consensus motifs, and the presence of a transit peptide, it is likely that $B o L O X$ encodes a $13-\mathrm{LOX}$ and not a 9-LOX.

\section{Accumulation of $B o L O X$ RNA in response \\ to treatment with the phytohomone JA.}

The levels of BoLOX transcripts in response to treatment with different doses of JA were investigated with RT-PCR, both conventionally and with real-time PCR. RNA was isolated from the leaves of three independent biological replicates, each consisting of a single plant. The transcript levels of BoLOX were normalized for transcript levels of the housekeeping gene glyceraldehyde-3-phosphate dehydrogenase $(G A P D H)$. Both conventional and real-time PCR showed an increase of BoLOX transcript levels in a JA-concentration-dependent fashion for all three experiments (Fig. 3). With increasing JA concentration from $0,10,100$, to $1,000 \mu \mathrm{M}$, the transcript level of $B o L O X$ significantly increased $24 \mathrm{~h}$ after spraying. We chose this time point because $B$. oleracea plants are most attractive to Cotesia glomerata wasps at $24 \mathrm{~h}$ after treatment with $1 \mathrm{mM}$ JA compared with 1, 2, 3, 4, 6, 48, 72, and $120 \mathrm{~h}$ (M. Bruinsma, J. J. van Loon, and M. Dicke, unpublished data). Moreover, the two butterfly species Pieris rapae and P. brassicae laid fewer eggs on leaves of JA-treated plants after $24 \mathrm{~h}$ compared with control plants (Bruinsma et al. 2007). At this time point, maximum BoLOX transcript levels were recorded in response to herbivory (discussed below). Plants showed no visual symptoms after application of any of the JA doses (data not shown). The 
GAPDH gene that was used as an internal reference showed a stable transcript level among different treatments (data not shown). Relative BoLOX transcript levels were 46-, 2,185-, and 14,230-fold, on average, after 10-, 100- and 1,000- $\mu \mathrm{M} \mathrm{JA}$ exposure, respectively, compared with control plants (Fig. 3).

\section{Dynamics of BoLOX RNA levels in response to feeding by different herbivores.}

Schistocerca gregaria locusts. A single first-instar locust had been placed on one of the youngest fully expanded leaves of each cabbage plant in order to use leaves of similar physiological state among different plants (Fig. 4B). The infested and damaged leaf was denoted as local leaf, whereas one undamaged leaf directly below the infested leaf was denoted as systemic leaf. The BoLOX transcript level was significantly increased 3 days later, both locally in the damaged leaf and in a systemic undamaged leaf. Real time RT-PCR showed 870, and 374-fold increase in BoLOX transcript levels in the local and systemic leaves, respectively, compared with control plants (Fig. 5).

Pieris and Mamestra caterpillars. Both the effect of caterpillar density and time of feeding on BoLOX transcript accumulation were investigated after infestation by caterpillars from the crucifer specialists $P$. rapae and $P$. brassicae (Fig. 4C and D) in a series of experiments. BoLOX RNA was visible by conventional RT-PCR after $24 \mathrm{~h}$ of feeding by one $P$. brassicae or $P$. rapae larva in the local (infested) leaf (Fig. 6A). BoLOX

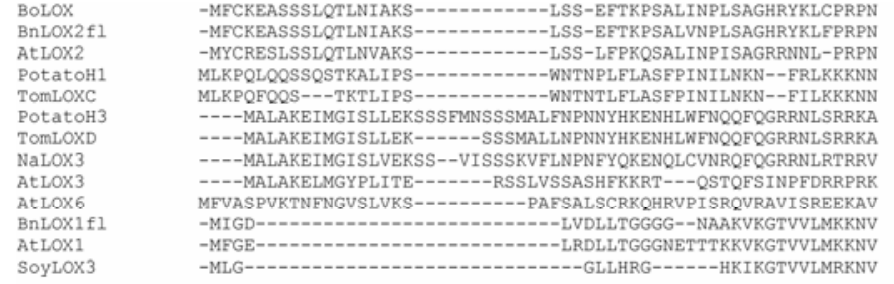

BOLOX

BnLOX2 1

AtLoX2 2

Potatoh1

PotatoH 3

Fomiox

NaLOX3

AtLOX3

AtLox 6

BnLOX1fi

AtLOX1

SoyLOX3

BoLOX

BnLOX 2 f 1

AtLOX2

PotatoH1

PotatoH

TomLOX

NaLOX3

AtLox3

BnLOX1f 1

SoyLoX

BOLOX

BnLOX2f1

PotatoH

PotatoH 3

Tomiox

NaLOX 3

Atrox

Bn $0 \times 1 f 1$

BnLOX1

SoyLox

\section{BoLOX}

BnLOX $2 \mathrm{fl}$

AtLOX2

TomLOXC

PotatoH 3

PotatoH 3

TomLOX

NaLOX3

AtLOX6

BnLOX1f1

SoyLox 3

BOLOX

BnLOX2f1

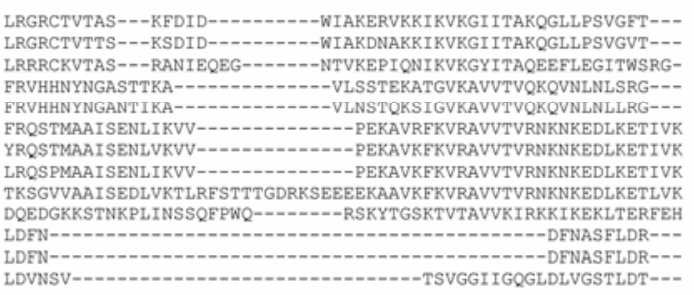

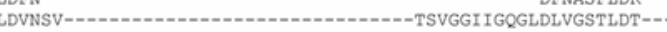

------DLLGVSLLVELISAETDPQTLMEKDPVKDHARRLVIDAHGEDQ------YECV

DLLGVSLLVELISAETDPRTLMEKDPVKDNARRVLLDAHGEDQ------YECV -LDDIADIRGRSLLVELISAKTD-----QRITVEDYAQRVWAEAP-DEK-------YECEF -LDDIGDLLGKSLLLWIVAAELDHKTGI EKPGI RAYAHR-GRDVDGDTH------YEADE -LDGIGDLLGKSLILWIVAAELDHKTGLEKPSIRSYAHR-GLDVDGDTY-----YEADF HLDAFTDKIGRNVALELISTDIDPDTKGPKKSNQAVLKDWSKKSNLKTERV---NYTAEF HLDAFTDKFGRNVSLELISTDIDPNTKGPKKSNQAVLKDWSKKSNLKTERV---NYTAE

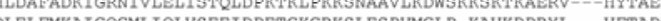
QLELMKAIGQGMLIQLUSEEIDPETGKRKSLESPMGLP-KAVKDPRYL- -VYAADF --LHEFLGNKITLRLVSSDVTDSENGSKGKLGKAAHLEDWITTITSLTAGESAFKVTF ----LTAFLGRPVSLQLISATKADAN--GKGKLGKATFLEGIITSLPTLGAGQSAFKINF

$\begin{array}{cl}* & :::: \\ \text { DMPKDFGAVGAIRVLNEAHREIFLKEMKLE-L-PDGPVTFTCNSWLASKSDDPTKRTFFS }\end{array}$

DMPKDFGAVGAIRVLNEAHREIFLKEMKLE-L-PDGPVTFTCNSWLASKSDDPTKRTFFS DMPEDFGVGAIRVLNQDLKEIFLKEMKLE-L-PDGSVTFTENSWVAPKSEDPTKRTFFS VIPQDFGEVGAILIENEHHKEMYVKNIVIDGF-VHGKVEITCNSWVHSKFDNPDKRIFFT EIPEDFGEVGAILVENEHHKEMYVKNIVIDGF-VHAKVEITCNSWVHSKFANPDKRIFF IVDSNFGNPGAITVTNKHQQEFFLESITIEGF-ACGPVHFPCNSWVQPKKDHPGKRIFFS IVDSNFGNPGAITVTNKHQQEFFLESITIEGF-ACGPVHFPCNSWVQPKKDHPGKRIFFS VVDSNFGTPGAITVTNKHQQEFFLESITIEGF-ACGPVHFPCNSWVQSKKDHPGKRIFFS TVDAAFGSPGAITVMNKHQKEFFLESITIEGF-ALGPVHFPCNSWVQSQKDHPDKRIFFT TVPINFGKPGAILVTNLLSTEICLSEIIIED--STDTILFPANTWIHSKNDNPQARIIFR DYDQDFGYPGAFLIRNSHFSEFYLKSLTLEDVPGHGRVHYICNSWVYPAKRYTKDRVFFS DYDQDFGYPGAFLIRNSHFSEFYLKSLTLEDVPGHGRVHYICNSWVYPAKRYTKDRVFFS DWETDFGYPGAFLIRNSHFSEFLLKSLTLEDVPGHGRVHYICNSWTYPAKHYTTDRVFFS

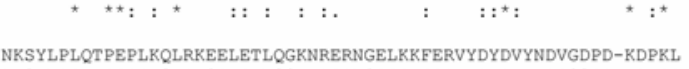
TKSYLPLKTPEPLKQLRKQELETLQGKNRERAGEFEKFERVYDYDVYNDLGSPD-KDPEL DKSYLPSQTPEPLKKYRKEELETLQGKNREEVGEFTKFERIYDYDVYNDVGDPD-NDPEI NKSYLPSOTPSGVSRLREEELVTLRG---DGIGERKVFERIYDYDVYNDLGEADSNNDD NKSYLPSOTPSGVIRLREGRTRTLRG---DGVGERKVFERIYDYDVYNDLGEVVSNNDDA NKSYLPSQTPSGVIRLREGRTRTLRG---DGVGERKVFERIYDYDVYNDLGEVVSNNDDA NQPYLDETPAGLKSLRERELRDLRG---DGKGVRKLSDRIYDYDIYNDLGNPD-KGID NQPYLPNETPAGLKSLRERELRDLRG---DGTGVRKLSDRVYDYDIYNDLGNPD-KGIDF NQPYLPNETPAGLKSLRERELRDLRG---DGTGVRKLSDRVYDYDIYNDLGNPD-KGIDF SQPCLPSETPDGI KELREKDLVSVRG---DGKGERKPHERIYDYDVYNDLGDPR-K-TER NKTYLPRETPEPLLKYREEELVSLRG---TGEGELKEWDRVYDYAYYNDLGVPP-K---N NKTYLPHETPATLLKYREEELVSLRG---TGEGELKEWDRVYDYAYYNDLGVPP-K---1 NQTYLPSETPAPLVKYREEELHNLRG---DGTGERKEWERVYDYDVYNDLGDPD-KGENH

SRPVLGGLS-HPYPRRCKTGRKPSRKYPSIETRKG-----DFYVPRDEEWSTVKGTAFT ARPILGGLS-HPYPRRCKTGRKPCDKDPSAETRKAL----EFYVPRDEEFTTVKGAOFTG

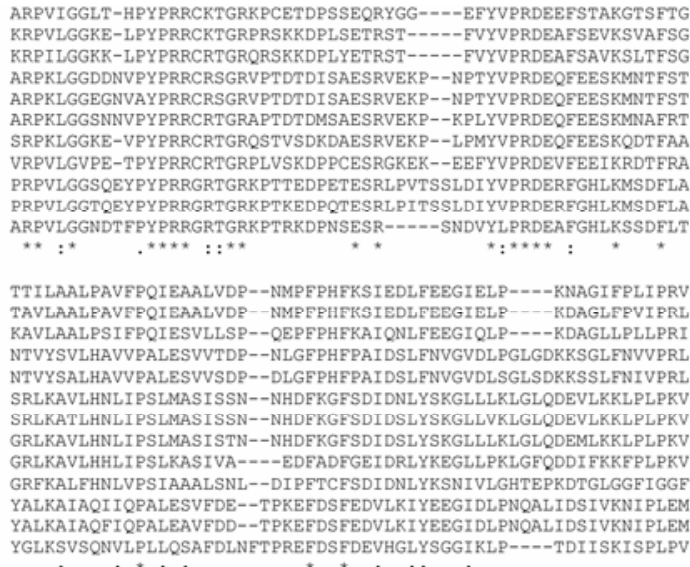

YGLKSVSQNVLPLLQSAFDLNFTPREFDSFDEVHGLYSGGIKLP----TDIISKISPLPV

VK-AVAEA-DDILQFDSPILLDKDRFSWIRDDEFARQTLAGLNPLCIGLVQEWPLKSKL AK-AAAEA-DDILQFESPSLLDKDRFSWIRDDEFVRQTLAGLNPYCIQLVQEWPLKSKLD IK-ALGEAQDDILQFDAPVLINRDRFSWLRDDEFARQTLAGLNPYSIQLVEEWPLISKLD IK-AISDTRKDVLLFESPQLVQRDKFSWFRDVEFARQTLAGLNPYSIRLVTEWPLRSKLD IK-SISETGKDVLLFESPQLVQRDKFSWFRDVEFARQTLAGLNPYSIRLVTEWPLRSNLD VS-SIKEG--DLLKYDTPKILSKDKFAWLRDDEFARQAIAGVNPVSIEKLQFFPPVSKLD VS-TIKEG--DLLKYDTPKILSKDKFAWLRDDEFARQAIAGVNPVSIEKLQVFPPVSKLD VS-SIQEG-DLLKYDTPKILSKDRFAWLRDDEFARQAIAGNNPVNIERLQVFPPVSKLD VVDTLQESTKGLLKYDTPKILSKDKNAWLRDDEFARQAIAGINPVNIERVKTFPPVSNLD MN-GILNVTETLLKYDTPAVI KWDRFAWLRDNEFGRQALAGVNPVNIELLKELPIRSNLD LKEI FRTDGQRFLKXPVPQVIKEDKTAWRTDEEFAREMLAGLNPVVIQLLKEFPPKSKLD LKEIFRTDGEQALKFPPPKVIQVSKSAWMTDEEFAREMLAGVNPNLIRCLKEFPPRSKLD

PAVYGDPNSLITSEIVEREIKG-VMSFDEALENKRLFMLDYHDLLLPYVNKVREL- DDS PAVYGDPNSLITSEIVEREIKG-YMSFDEALENKRLFMLDYHDLLLPYVNKVREL--DDS PAVYGDPTSLITWEIVEREVKG-NMTVDEALKNKRLFVLDYHDLLLPYVNKVREL--NNT PKVYGPPESEITKELIEKEIGN-YMTVEQAVQQKKLFILDYHDLLLPYVNKVNEL--KGS PKVSGPPESEITKELI I ENEI GN-NMTVEQAVQQKKLFI LDYHDLLLPYVNKVNEL--KGS PEIYGPQESALKEEHILGHLN--GMTVQEALDANKLFIVDHHDVYLPFLDRINAL--DGR PEIYGPQESALKEEHILGHLN--GMTVQEALDANKLFILDHHDVYLPFLDRINAL--DGR PEIYGTQESALKEEHILGHLN--GMTVQEALDANRLYIVDYHDVYLPFLDRINAL--DGR PKIYGPQHSALTDDHI IGHLD--GFSVQQALEENRL YMLDYHDIFLPFLDRINAL--DGR PALYGPQESVLTEEIIAREVEHYGTTIEKALEEKRLFLVDYHDILLPFVEKINSIKEDPR RETYGGQNSTFTKSHIEQSLDG--LTVEEALEKERLFILDHHDTLMPYLGRINTT---GN SESYGNQNSTITKSHIEHNLDG--LTVEEALEKERLFILDHHDTLMPYLGRVNTT---TT SQVYGDHTSQITKEHLEPNLEG--LTVDEAIQNKRLFLLGHHDPIMPYLRRINAT---ST

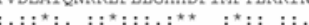

TLYASRTLFFLNDDSTLRPVAIELTRPQD--VNRPQWSQVFTPG-YDATSCWLWNLAKTH TLYASRALFFLSDDSTLRPVAIELTRPQD--VNRPQWRQVETPG-YDATSCWLWILAKTH TLYASRTLFFLSDDSTLRPVAIELTCPPN--INKPQWKQVFTPG-YDATSCWLWNLAKTH MLYGSRTIFFLTPQGTLKPLAIELTRPPV--DDKPQWKEVYSPNDWNATGAWLWKLAKAH KAYATRTIFFLSDVGTLKPIAIELSLPQT--GPSSRSKRVVTPP-VCATGNWTWQIAKAH KAYATRTIYFLSDVGTLKPIAIELSLPQT--GPSSRSKRVVTPP-VCATGNWMWQIAKAH KAYATRTIFFLSDLGTLKPIAIELSLPQT--GPSSRSKRVVTPP-VDATGNWMWQLAKAH KAYATRTIFFLSDLGTLKPIAIELSLPQT--GPSSRSKRVVTPP-VDATGNWMWQLAKA KAYATRTIFFLTRLGTLKPVAI ELSLPPH--GPKHRSKRVLTPP-VDATSNWMWQLAKA: KVYASRTLLFLKDDGTLKPLVIELSLPHPDGDSFGAVSEVYTPG-EGVYDS-LWQLAKAY KTYASRTLLFLKDDGTLKPLVIELSLPHPNGDKFGAVSEVYTPG-EGVYDS-LWQLAKAF KAYATRTILFLKNDGTLRPLAIELSLPHPQGDQSGAFSQVFLPADEGVESS-IWLLAKAY

$*:^{\star}::^{*},:^{\star}::^{\star}:{ }^{* \star \star}:$

AITHDAGYHQLISHWLRTHCCMEPYIIAANRQLSAMHPIYRLLHPHFRYTLEINARARQS ISHDAGYHQLISHWLRTHCCIEPYI IAANRQLSAMHPIYRLLHPHFRYTMEINARARQ AISHDAGYHQLISHWLRTHACTEPYIIAANRQLSAMHPIYRLLHPHFRYTMEINARARQS Continued on following page

Fig. 1. Clustal X (1.83) multiple alignment of deduced amino acid sequence of Brassica oleracea lipoxygenase (BoLOX) with other selected LOXs. The consensus amino acid sequence of nearly all known plant LOX sequences HAAVNFGQY is underlined. Accessions for LOX amino sequences represented in this alignment are Arabidopsis thaliana AtLOX1(NM 104376); A. thaliana AtLOX2 (L23968); A. thaliana AtLOX3 (AJ249794); A. thaliana AtLOX6 (AJ748537), Solanum tuberosum potato H1(X96405), S. tuberosum potato H3(X96406), Nicotiana attenuata NaLOX3 (AY254349), Lycopersicon esculentum TomLOXC (U37839); L. esculentum TomLOXD(U37840), Glycine max SoyLOX3 (X13302), B. napus BnLOX1fl (AY162142), and BnLOX2 fl (AY162143). Asterisks (*) indicates identical amino acid residues, while colons (:) indicate low and high homologous amino acid residues, respectively. 
RNA accumulation was not detected in control plants (data not shown). The BoLOX transcript levels were much higher in both local and systemic leaves after $24 \mathrm{~h}$ of feeding by 1 to $32 P$. rapae larvae compared with $P$. brassicae (Fig. 6A). With increasing numbers of $P$. rapae larvae (from 1 to $2,4,8,16$, and 32 ), the relative $B o L O X$ transcript level in the local leaf was significantly increased 894-, 2,769-, 2,961-, 5,663-, 8,980-, and 9,796-fold compared with the undamaged control (Fig. 6B). When the larval density was increased from 2 to 32 caterpillars, BoLOX transcript levels in the local leaf were similar $(P>0.05)$. In the systemic (noninfested) leaf, there was a significant increase in $B o L O X$ transcript level as well, albeit much lower. The relative $B o L O X$ transcript level in the systemic leaf was increased 45-, 169-, 54-, 274-, 265-, and 986-fold after feeding by $1,2,4,8,16$, or 32 larvae, respectively, compared with an undamaged control plant (Fig. 6B). BoLOX transcript levels in the systemic leaf were independent of caterpillar density (from 1 to $32 ; P>0.05$ ).

\begin{tabular}{|c|c|c|}
\hline TomLOXC & VLSHDSGYHQLVSHWLRTHCCTEPYI IATNRQLSAMHPI YRLLHPHFRYTMEINALAREA & TOMLOXD \\
\hline PotatoH3 & VCANDAGVHQLVNHWLRTHASLEPFILAAHRQLSAMHPIYKLLDPHMRYTLEINGLARQS & NaLOX3 \\
\hline TOMLOXD & VCANDAGVHQLVNHWLRTHASLEPFILAAHRQLSAMHPIYKLLDPHMRYTLEINGLARQS & AtLOX3 \\
\hline NaLox 3 & VCSNDAGVHQLVNHWLRTHACLEPFILAAHRQLSAMHPI YKLLDPHMRYTLEINALARQS & AtLox6 \\
\hline AtLOX3 & VSSNDAGVHQLVNHWLRTHACLEPFILAAHRQLSAMHPI FKLLDPHMRYTLEINALARQS & BnLOX $1 \mathrm{f} 1$ \\
\hline AtLOX6 & VCSNDAGVHQLVNHWLRTHASMEPYI IATNRQLSTMHPVYKLLHPHMRYTLEINARARKS & AtLOX1 \\
\hline BnLOX1f1 & VGVNDSGNHQLISHWLQTHASIEPFVIATNRQPSVLHPVFKLLEPHYRDTMNI NALARQI & SoyLOX3 \\
\hline AtLOX1 & VGVNDSGNHQLISHWMQTHASIEPFVIATNRQLSVLHPVFKLLEPHFRDTMNINALARQI & \\
\hline \multirow[t]{2}{*}{ SoyLOX3 } & VVVNDSCYHQLVSHWLNTHAVVEPFI I ATNRHLSVVHPI YKLLHPHYRDTMNI NGLARLS & \\
\hline & 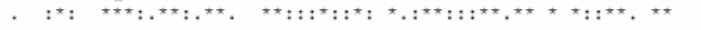 & \\
\hline BOLOX & LVNAGGI IETCFWPGKYSLELSSDVYAKLWRFDREGLPADLISRGLAVEDETAEHGLRLT & \\
\hline BnLOX2f1 & LINEGGIIESRFWPGKYSLELSSDVYDKLWRFDREGLPADLIGRGLAVEDETAEHGVRLT & \\
\hline AtLOX2 & LVNGGGI IETCFWPGKYALELSSAVYGKLWRFDQEGLPADLI KRGLAEEDKTAEHGVRLT & \\
\hline PotatoH1 & LINANGVIESSFFPGKYAIELSSIAYGAEWRFDQEALPQNLISRGLAVEDPNEPHGLKLA & \\
\hline TOMLOXC & LINANGIIESSFFPGKYSVELSSIAYGAEWRFDQEALPQNLISRGLAEEDPNEPHGLKLA & \\
\hline PotatoH3 & LINADGVIEACFTPGRYCMEISAAAYKN-WRFDLEGLPADLIRRGMAVPDSTQPHGLKLL & \\
\hline TOMLOXD & LINADGVI EACFTPGRYCMEISAAAYKN-WRFDLEGLPADLIRRGMAVPDATQPYGLKLL & \\
\hline NaLOX3 & LISADGVI EACFTPGRYCMEMSAAAYKNLWRFDLEGLPADLIRRGMAVPDPTQPHGLKLL & \\
\hline AtLOX3 & LISADGVI EGGFTAGAYGMEMSAAAYKSSWRFDMEGLPADLIRRGMAI PDATQPHGLKLL & \\
\hline AtLOX6 & LINGGGI IESCFT PGKYAMELSSAAYKSMWRFDMEGLPADLVRRGMAEEDSSAECGVRLV & \\
\hline BnLOX1fi & LINGGGI FEITVFPSKYAMEMSSFIYKNHWTFPDQALPAELKKRGMAVEDPEAPHGLRLR & \\
\hline At LOX1 & LINGGGI FEITVFPSKYAMEMSSFIYKNHWTFPDQALPAELKKRGMAVEDPEAPHGLRLR & \\
\hline \multirow[t]{2}{*}{ SoyLOx3 } & LVNDGGVIEQTFLWGRYSVEMSAVVYK-DWVFTDQALPADLIKRGMAIEDPSCPHGIRLV & \\
\hline & 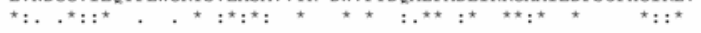 & \\
\hline BoLOX & IPDYPFANDGLMLWDALKEWITECVKHYYPDAALIMCDEELQAWWSEVRNIGHGDKKDEP & \\
\hline BnLOX $2 \mathrm{f1}$ & IPDFPFANDGLMLWDALKEWVTDYVNHYYPDSEQVTLDEELQGWWSEVRNIGHGDKKNEP & \\
\hline AtLOX 2 & IPDYPFANDGLILWDAI KEWVTDYYVKHYYPDEELITSDEELQGWWSEVRNIGHGDKKDEP & \\
\hline PotatoH1 & IEDYPFANDGLVLWDI LKQWVTNYVNHYYPQTNLIESDKELQAWWSEIKNVGHGDKRDEP & \\
\hline TomLOXC & IEDYPFANDGLVLWDI LKQWVTNYVNHYYPQTNLIESDKELQAWWSEI KNVGHGDKKDEP & \\
\hline PotatoH3 & IEDYPYAADGLMI WGAIESWVRDYVNHYYPSSAQVCSDRELQAWYAET INVGHVDLRNEE & \\
\hline TOMLOXD & IEDYPYAADGLMIWGAIEGWVRDYVDHYY PSSAQVCSDRELQAWYTET INVGHVDLRNED & \\
\hline NaLox3 & IEDYPYAADGLMIWAAIEGWVRSYVNHYYPDSAQVCNDRELQAWYAES INVGHADLRNEE & \\
\hline AtLOX3 & IEDYPYANDGLLLWSAIQTWVRTYVERYYPNPNLIKTDSELQSWYSESINVGHADLRDAD & \\
\hline AtLOX6 & IDDYPYAADGLLIWKAI KDLVESYVKHFYSDSKSIT SDLELQAWWDEI KNKGHYDKKDEP & \\
\hline BnLOX1f1 & IEDYPYAVDGLEVWYAIESWVQDYIPLYYKTDEDVQNDTELOAWWKEVREEGHGDKKSEP & \\
\hline AtLOX1 & IKDYPYAVDGLEVWYAIESWVRDYIFLFYKIEEDIQTDTELQAWWKEVREEGHGDKKSEP & \\
\hline \multirow[t]{2}{*}{ SoyLOX3 } & IEDYPYAVDGLEIWDAIKTWVHEYVFLYYKSDDTLREDPELQACWKELVEVGHGDKKNEP & \\
\hline & 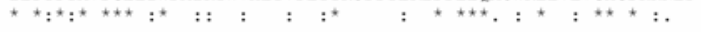 & \\
\hline BOLOX & WWPVLRTQDDLIGVVTTIAWVASGHHAAVNFGQYGYGGYFPNRPTTTRIRMPVEEPTEEE & \\
\hline BnLOX2f1 & WWPVLKTQDDLIEVVTTIAWVASGHHAAVNFGQYGYGGYFPNRPTTSRI KMPVEEPTDEE & \\
\hline AtLOX2 & WWPVLKTQDDLIGVVTTIAWVTSGHHAAVNFGQYGYGGYFPNRPTTTRIRMPTEDPTDEA & \\
\hline PotatoH1 & WWPELKTPNDLIGI ITTIVWVTSGHHAAVNFGQYSYAGYFPNRPTVARSKMPTEDPTAEE & \\
\hline TOMLOXC & WWPELKTPNDLIGI ITTIVWVTSGHHAAVNFGQYSYGGYFPNRPTTARSKMPTEDPTAEE & \\
\hline PotatoH3 & WWPTLATPEDLISILTTLIWLASAQHAALNFGQYPYGGYVPNRPPLMRRLIPDEN--DPE & \\
\hline TOMLOXD & WWPTLATPEDLISI LTTLIWLASAQHAALNFGQYPYSGYVPNRPPLMRRLIPDEN--DPE & \\
\hline NaLOX3 & WWPTLATPEDLISILTTLIWLASAQHASLNFGQYPYGGYVPNRPPLMRRLI IPDEN--DPE & \\
\hline AtLOX3 & WWPELSTVDDLVSILTTLIWLASAQHAALNFGQYPYGGYVPNRPPLMRRLIPDES--DPE & \\
\hline AtLOX6 & WWPKLNTTQDLSQILTNMIWIASGQHAAINFGQYPFGGYVPNRPTLLRKLI PQET--DPD & \\
\hline BnLOX1f1 & WWPKMQTRKELIDSCTI I IWVASALHAAVSFGQYPIAGYLPNRPTISRQFMPKEN--TPE & \\
\hline AtLOX1 & WWPKMQTREELVESCTII I WVASALHAAVNFGQYPVAGYLPNRPTISRQYMPKEN--TPE & \\
\hline \multirow[t]{2}{*}{ SoyLox3 } & WWPKMQTREELVEACAII IWTASALHAAVNFGQYPYGGLILNRPTLSRRFMPEKG--SAE & \\
\hline & 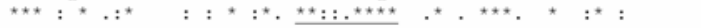 & \\
\hline BOLOX & LKEFYEEPEKVLLKTFPSQKQATQVMVTLDLLSTHSPDEEYLGE--EPEASWVDDPVIFA & \\
\hline BnLOX $2 f 1$ & LKEFYEDPEKTMLKTFPSKKQATIVMVTLDLLSAHSPDEEYLGE--NPEASWAHEPVIYA & \\
\hline AtLOX2 & LKEFYESPEKVLLKTYPSQKQATLVMVTLDLLSTHSPDEEYIGE--QQEASWANEPVINA & \\
\hline PotatoH1 & WEWFMNKPEEALLRCFPSQI QATKVMAILDVLSNHSPDEEYIGE--KIEPYWAEDPVINA & \\
\hline TOMLOXC & WEWFLNKPEEALLRCFPSQIQATKVMTILDVLSNHSPDEEYIGE--KIEPYWAEDPVINA & \\
\hline PotatoH3 & YAVFLADPQKYFFSALPSLLQATKFMAVVDTLSTHSPDEEYLGE-RHQPSTWTGDAEIVE & \\
\hline TOMLOXD & YAVFLADPQKYFFSALPSLLQATKFMAVVDTLSTHSPDEEYIGE-RQQPSTWTGDAEIVE & \\
\hline NaLOX 3 & YAVFHDDPQKYFFSALPSLLQATKFMAVVDTLSTHSPDEEYIGD-RHQPSTWTGDAEIVE & \\
\hline AtLOX3 & YASFISHPEKYYFSSMPSLAQTSKFMAVVDTLSTHSPDEEYIGE-RQQPSIWTGDAEIVE & \\
\hline AtLox 6 & YEMFMRNPQYSFLGSLPTQLQATKVMAVQETLSTHSPDEEYLIELREVQRHWFQDEQVVK & \\
\hline BnLOX1f1 & FEELEKNPDKVFLKSITAQLQTLLGISLIEILSTHSSDEVYLGQ--RDSKEWAAEKEALE & \\
\hline & FEELEKNPDKVFLKTI TAQLQTLLGISLIEILSTHSSDEVYLGQ--RDSKEWAAEKEALE & \\
\hline \multirow[t]{2}{*}{ SoyLOX3 } & YEELRKNPQKAYLKTITPKFOTLIDLSVIEI LSRHASDEVYLGE--RDNPNWTSDTRALE & \\
\hline & 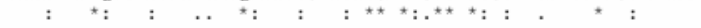 & \\
\hline BoLOX & AYERFKGRLKHLEDVIDERNVNVSLKNRAGAGVVKYELLKPISQPGVTGMGVPYSVSI & \\
\hline BnLOX $2 f 1$ & AYERFKGKLQYLEGVIDERNVNVSLKNRTGAGVVKYELLKPISEPGVTGMGVPYSVSI & \\
\hline AtLOX2 & AFERFKGKLQYLEGVIDERNVNITLKNRAGAGVVKYELLKPTSEHGVTGMGVPYSISI & \\
\hline PotatoH1 & AFEVFSGKLKELEGI I DARNNDSKLSNRNGAGVMPYELLKPYSEPGVTGKGVPYSISI & \\
\hline TOMLOXC & AFEVFSSKLLKELEGI I DARNNDSKLNNRNGAGVMPYELLKPYSEPGVTGKGVPYSISI & \\
\hline PotatoH3 & AFYKFSAEIGRIEKEIDERNANTKLKNRCGAGVLPYELLAPSSGPGVTCRGVPNSVSI & \\
\hline
\end{tabular}

Because feeding for $24 \mathrm{~h}$ by only one first-instar $P$. brassicae or $P$. rapae larva was sufficient to induce $B o L O X$ transcripts (Fig. 6A), we investigated the temporal pattern in $B o L O X$ transcripts in response to feeding by one first-instar larva for both $P$. rapae and $P$. brassicae. As assessed by conventional RT-PCR, accumulation of BoLOX RNA could be visualized only after at least $24 \mathrm{~h}$ of caterpillar feeding, in both the local and systemic leaves (data not shown). There was no BoLOX RNA accumulation detected in control plants (data not shown). Relative BoLOX transcript levels were significantly increased 9-, 25-, 1,274-, 1,488-, 1,658- and 1,930-fold in the local leaf after feeding by one first-instar $P$. brassicae caterpillar for 1 to $96 \mathrm{~h}$ (Fig. 7). In the systemic leaf, the induction was much lower than in the local leaf; the relative $B o L O X$ transcript level in the systemic leaf was increased only 5-, 5-, 81-, 120-, 165-, and 193-fold compared with the undamaged control plants (Fig. 7). In the systemic leaves, $B o L O X$ transcripts were induced significantly only after $24 \mathrm{~h}$ and longer. BoLOX transcript levels were similar after cat-

AFYKFSAEIGRIEKEIDERNADTNLKNRCGAGVLPYELLAPSSGPGVTCRGVPNSVSI AFYDFSSEIRRIEKEIDDRNADTRLRNRCGAGVLPYELLAPSSGPGVTCRGVPNSSI AFYGFAAEIGRIEKEIEKRNADPDRRNRCGAGVLPYELLVPSSEPGVTCRGVPNSVSI YFNKFSEELVKIEKTINERNKDKKLKNRTGAGMPYELLLPTSPHGVTGRGIPNSISI AFEKFGEKYKEIEKNTDERNDDETLKMRTGLVKMPYTLLFPSSEGVTGRGIPNSVSI AFKRFGNKLAQI ENKLSERNNDEKLRNRCGPVQMPYTLLLPSSKEGLTFRGI PNSISI

Fig. 1. Continued from previous page. 
erpillar feeding times that ranged from 24 to $96 \mathrm{~h}$ in both the local and systemic leaves. We also investigated the BoLOX transcript pattern after feeding by one first-instar larva of the generalist caterpillar Mamestra brassicae in several independent experiments. Results were quite similar to those for the specialists $P$. rapae and $P$. brassicae. Induced $B o L O X$ transcript level as assessed by RT-PCR was apparent after $24 \mathrm{~h}$ of feeding by one M. brassicae caterpillar in the local leaf; after $72 \mathrm{~h}$ and 7 days, BoLOX transcripts were clearly present in both the local and systemic leaf (data not shown).

Tetranychus urticae spider mites. After an infestation with at least 50 spider mite females for 3 days, the damage to plants by spider mites was different compared with feeding damage inflicted by locusts and caterpillars. No clearly visible damage symptoms were observed up to 3 days after infestation (Fig. 4E). After 7 days, white spots were visible where the spider mites had emptied the content of parenchymous cells. On average, relative $B o L O X$ transcript levels were increased 487- and 120-fold compared with control plants after 3 and 7 days, respectively (Fig. 8). BoLOX transcript levels were similar after 3 and 7 days of spider-mite infestation $(P>0.05)$.

Myzus persicae aphids. Green peach aphids (Myzus persicae) are generalists that feed on phloem sap. In our studies, $M$. persicae were allowed to feed for 7 days on the plants, resulting in a clear suppression of growth rate of plants when compared with healthy control plants (Fig. $4 \mathrm{~F}$ and $\mathrm{G}$ ). Severe effects of aphids on plant growth also occur in other plants (Mornhinweg et al. 2006). However, no BoLOX RNAs were detected by RTPCR (data not shown).

\section{Accumulation of $\mathrm{BoLOX}$ transcripts}

\section{in response to mechanical damage.}

After wounding plants by making three 2.5 -cm-diameter punches in each of two fully expanded young leaves, there was no other obvious change in the remaining leaves of plants compared with control plants (Fig. $4 \mathrm{H})$. BoLOX RNA was not detected 1,6 , and $24 \mathrm{~h}$ after mechanical damage by RT-PCR (data not shown). BoLOX RNA could be detected 3 days after the infliction of mechanical damage in the local leaf, but not in the systemic leaf by RT-PCR (Fig. 9A). The relative BoLOX transcript level in the local leaf was significantly increased 141-fold.

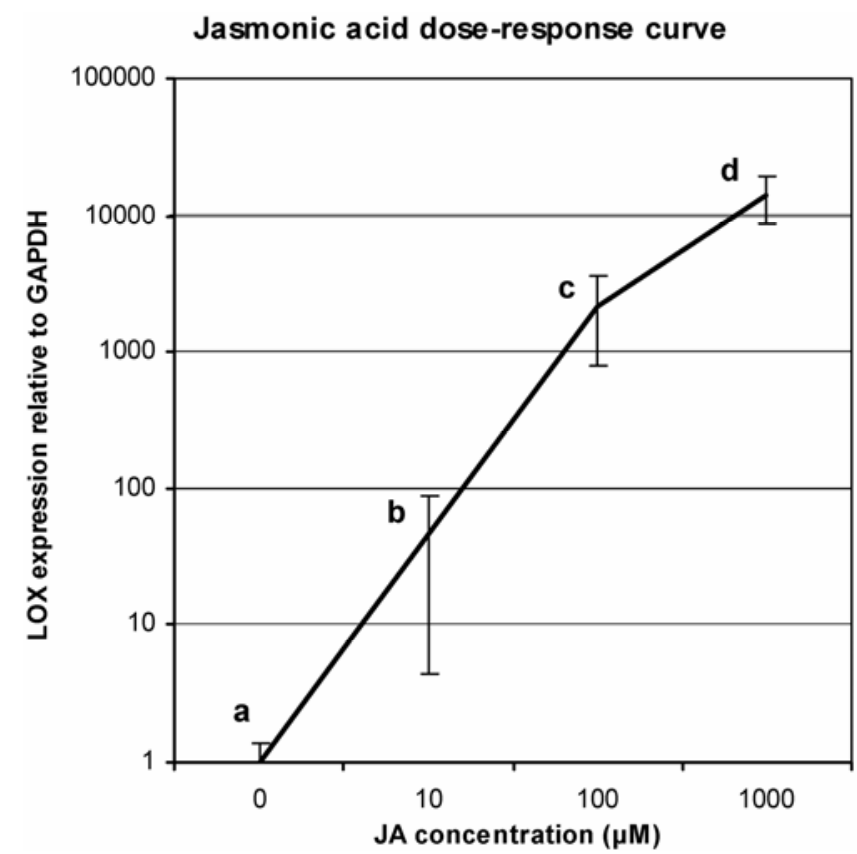

Fig. 3. Quantitative real-time polymerase chain reaction of Brassica oleracea lipoxygenase $(B o L O X)$ gene expression $24 \mathrm{~h}$ after exposure of $B$. oleracea plants to different jasmonic acid (JA) concentrations. JA-induced transcripts were quantified in three independent experiments at concentrations of 0,10 , 100 , and 1,000 $\mu \mathrm{M} \mathrm{JA}$. BoLOX transcript levels are presented relative to transcript levels of the housekeeping gene glyceraldehyde-3-phosphate dehydrogenase $(G A P D H)$ after application of JA. Error bars indicate standard error of the mean $(n=3)$. Data points marked with different letters are significantly different (Kruskal-Wallis test, $\alpha=0.05$ ).

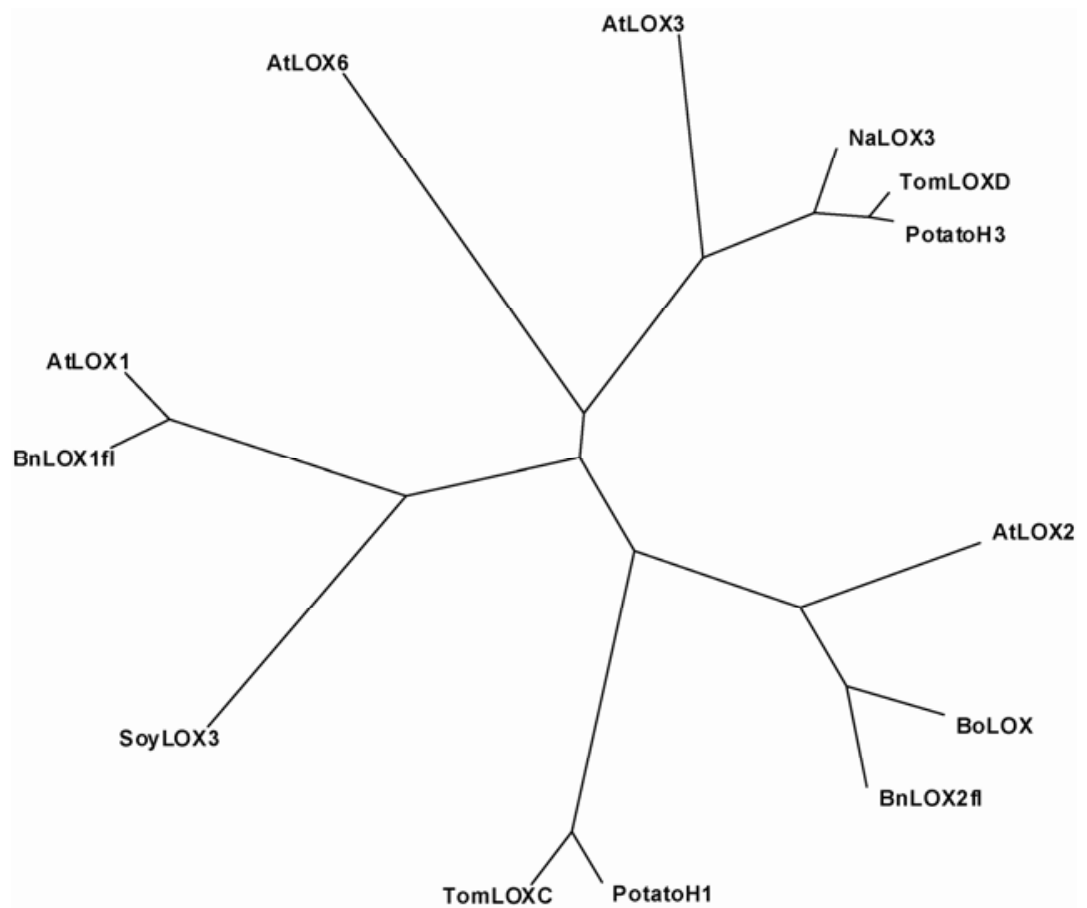

Fig. 2. Phylogenetic tree of lipoxygenase ( $L O X)$ genes from different plant species. Accessions for LOX amino sequences represented in this tree are Arabidopsis thaliana AtLOX1(NM 104376); A. thaliana AtLOX2 (L23968); A. thaliana AtLOX3 (AJ249794); A. thaliana AtLOX6 (AJ748537), Solanum tuberosum potato H1(X96405), S. tuberosum potato H3(X96406), Nicotiana attenuata NaLOX3 (AY254349), Lycopersicon esculentum TomLOXC (U37839); L. esculentum TomLOXD(U37840), Glycine max SoyLOX3 (X13302), B. napus BnLOX1fl (AY162142), and BnLOX2 fl (AY162143). 
The level of BoLOX transcript level in the systemic leaf was similar to that in the undamaged control plants (Fig. 9B).

\section{Accumulation of $B o L O X$ transcripts in response} to the bacterial pathogen Pseudomonas syringae.

Pseudomonas syringae is a virulent bacterial leaf pathogen that causes extensive chlorosis and necrotic spots (Whalen et al. 1991). P. syringae pv. tomato elicits a hypersensitive response in Chinese cabbage (Ryang et al. 2002). In our experiments, infiltration of cabbage plants with $P$. syringae pv. tomato DC3000 was carried out. Chlorosis symptoms in cabbage leaves were apparent at $48 \mathrm{~h}$ post infiltration (hpi,) (Fig. 4I). Necrotic spots were visible after 72 hpi (Fig. 4J). Furthermore, necrotic spots spread into larger leaf areas after 96 hpi (Fig. 4K and L). To analyze BoLOX RNA levels in response to bacterial infiltration, RNA was isolated from cabbage leaves at different time points after treatment with $P$. syringae pv. tomato DC3000 and subjected to RT-PCR analysis (Fig. 10). Before the appearance of chlorosis and necrosis, BoLOX transcripts accumulated. A transient increase was observed, starting even at $1 \mathrm{hpi}$ in the local leaf, but BoLOX RNA levels were highest at 1 and 6 hpi in the systemic leaf. BoLOX transcripts reached maximal levels in both local and systemic leaves after 24 hpi and declined after 48 hpi. However, BoLOX transcript levels went up again after 72 and 96 hpi, respectively. Because BoLOX RNA was not detected 1,6 , and $24 \mathrm{~h}$ after the infliction of mechanical damage by RT-PCR (Fig. 9A), we assume that mechanical damage by the act of infiltration itself will not lead to accumulation of BoLOX RNAs because it is a minor wounding compared with the mechanical damage we applied. However, this still needs to be verified by investigating the effect of infiltra-
Infestation with one locust for 72 hours

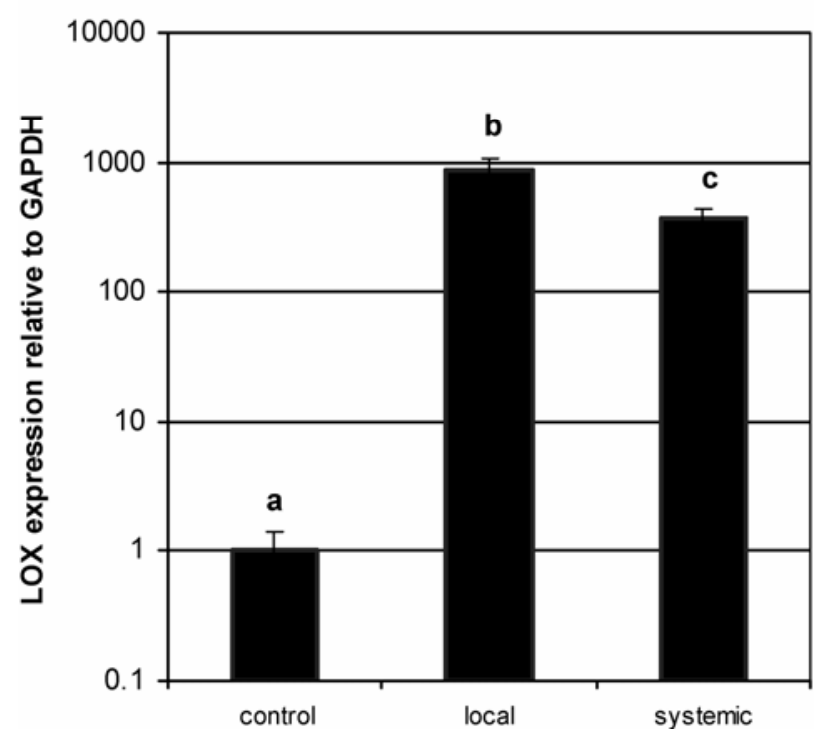

Fig. 5. Quantitative real-time polymerase chain reaction of Brassica oleracea lipoxygenase (BoLOX) gene expression. Relative BoLOX transcript levels in local, locust-damaged leaves (L) and systemic, undamaged leaves (S) after infestation of plants with one first-instar locust per plant for $72 \mathrm{~h}$. Error bars indicate standard error of the mean $(n=3)$. Data points marked with different letters are significantly different (Kruskal-Wallis test, $\alpha=0.05$ ).
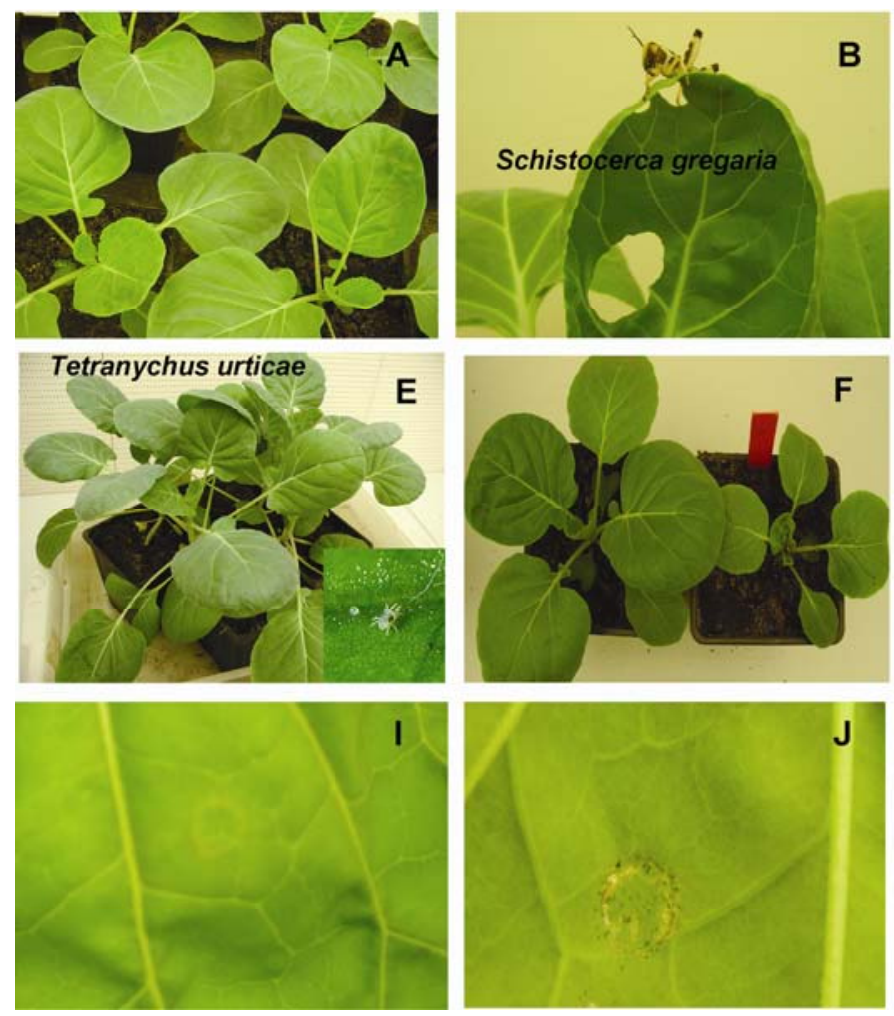
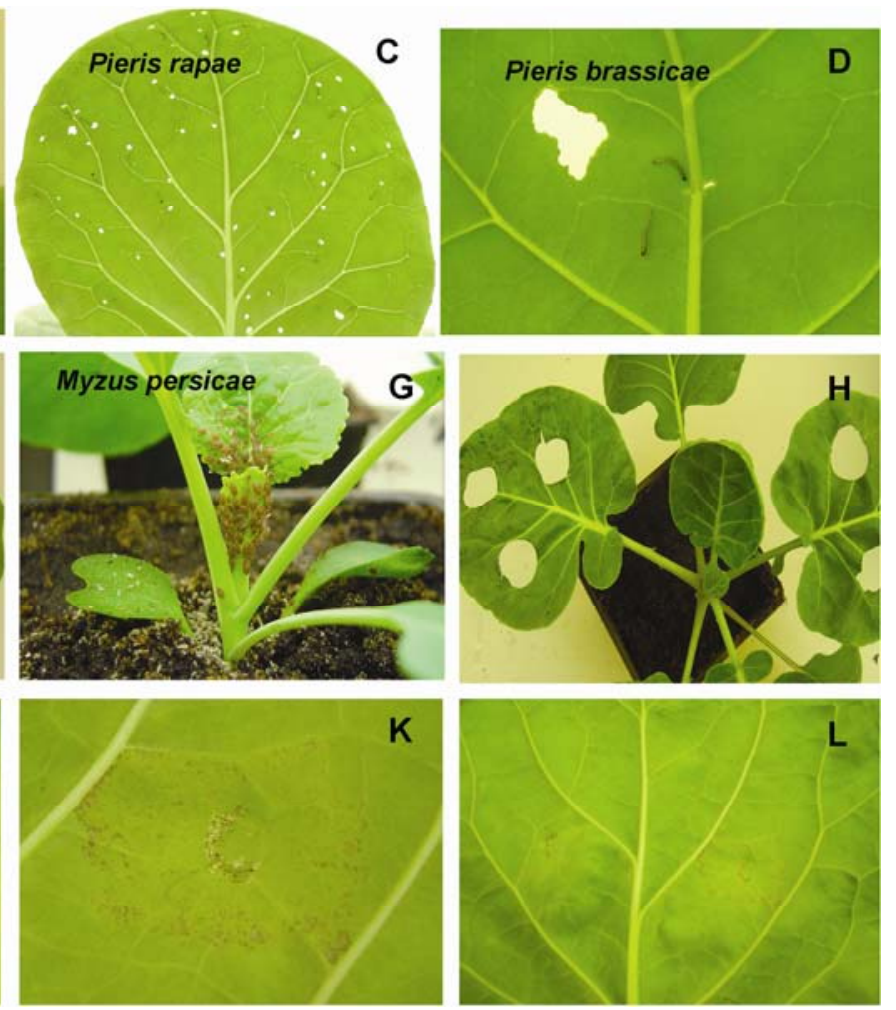

Fig. 4. Cabbage plants were infested with different herbivores, wounded by mechanical damage, or inoculated with a bacterial leaf pathogen. A, Overview of morphologically uniform plants used in experiments. B, Plant infested with one first-instar Schistocerca gregaria for $72 \mathrm{~h}$. C, Plant infested with 32 firstinstar larvae of Pieris rapae for $24 \mathrm{~h}$. D, Plant infested with two first-instar larvae of P. brassicae for $24 \mathrm{~h}$. E, Plants infested with Tetranychus urticae spider mites for 3 days. F, Untreated control plant (left) and plant infested with Myzus persicae aphids for 7 days (right). G, Plant infested with M. persicae after 7 days. H, Plant at 3 days after mechanical damage with a total three punches in each of two leaves. I, Leaf symptoms after inoculation with Pseudomonas syringae pv. tomato DC3000 for $48 \mathrm{~h}$. J, Leaf symptom after inoculation with $P$. syringae pv. tomato DC3000 for $72 \mathrm{~h}$. K, Leaf symptoms after inoculation with P. syringae pv. tomato DC3000 for $96 \mathrm{~h}$. L, Overview of leaf symptoms after inoculation with P. syringae pv. tomato DC3000 for $96 \mathrm{~h}$. 
tion on BoLOX transcript levels. The pattern of BoLOX RNA accumulation in response to $P$. syringae was recorded in all three independent experiments.

\section{DISCUSSION}

Isolation and characterization of $\mathrm{BoLOX}$.

LOXs compose a gene family with two subgroups. Class 2 LOXs carry a putative chloroplast transit peptide and are 13LOXs that oxygenate linolenic acid at the 13th carbon atom (Feussner and Wasternack 2002). A 13-LOX is required for the first step in the biosynthesis of JA from linolenic acid (Feussner and Wasternack 2002; Wasternack et al. 2006). The class 2 LOXs include AtLOX2 in Arabidopsis (Bell et al. 1995), TomLOXD in tomato (Heitz et al. 1997), LOX-H1 and LOX-H3 in potato (Royo et al. 1996), ZmLOX10 in maize (Nemchenko et al. 2006), and NaLOX3 in Nicotiana attenuata (Halitschke and Baldwin 2003) that are wound and jasmonate inducible. Antisense LOX expression of AtLOX2 or NaLOX3 reduced JA accumulation (Bell et al. 1995; Halitschke and Baldwin 2003) and direct or indirect defense (Halitschke and Baldwin 2003; Van Poecke and Dicke 2002), thus showing the involvement of these LOXs in the biosynthesis of JA. Here, we have sequenced a $L O X$ from $B$. oleracea $(B o L O X)$ that codes for a protein with a putative chloroplast transit peptide. Phylogenetic analysis shows that the sequence of this $L O X$ is closely related to that of other LOXs from brassicaceous plants, among which is AtLOX2 that codes for a protein involved in JA biosynthesis. Just like other class $2 L O X \mathrm{~s}$, $B o L O X$ RNA levels also are elevated after treatments by JA and wounding. Thus, BoLOX shares characteristics with many $L O X$ genes in class 2 that code for enzymes involved in an early step in JA biosynthesis. JA mediates direct (van Dam et al. 2004) as well as indirect defenses against insects in B. oleracea (Bruinsma et al. 2007). Direct defense of B. oleracea includes the induction of secondary metabolites such as glucosinolates (van Dam et al. 2004) and indirect defense of $B$. oleracea includes the production of parasitoid-attracting vola-

A

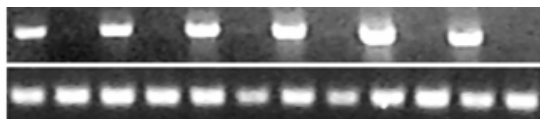

P. brassicae

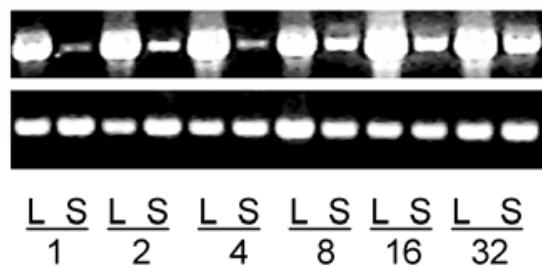

P. rapae

B

\section{P. rapae dose effect}

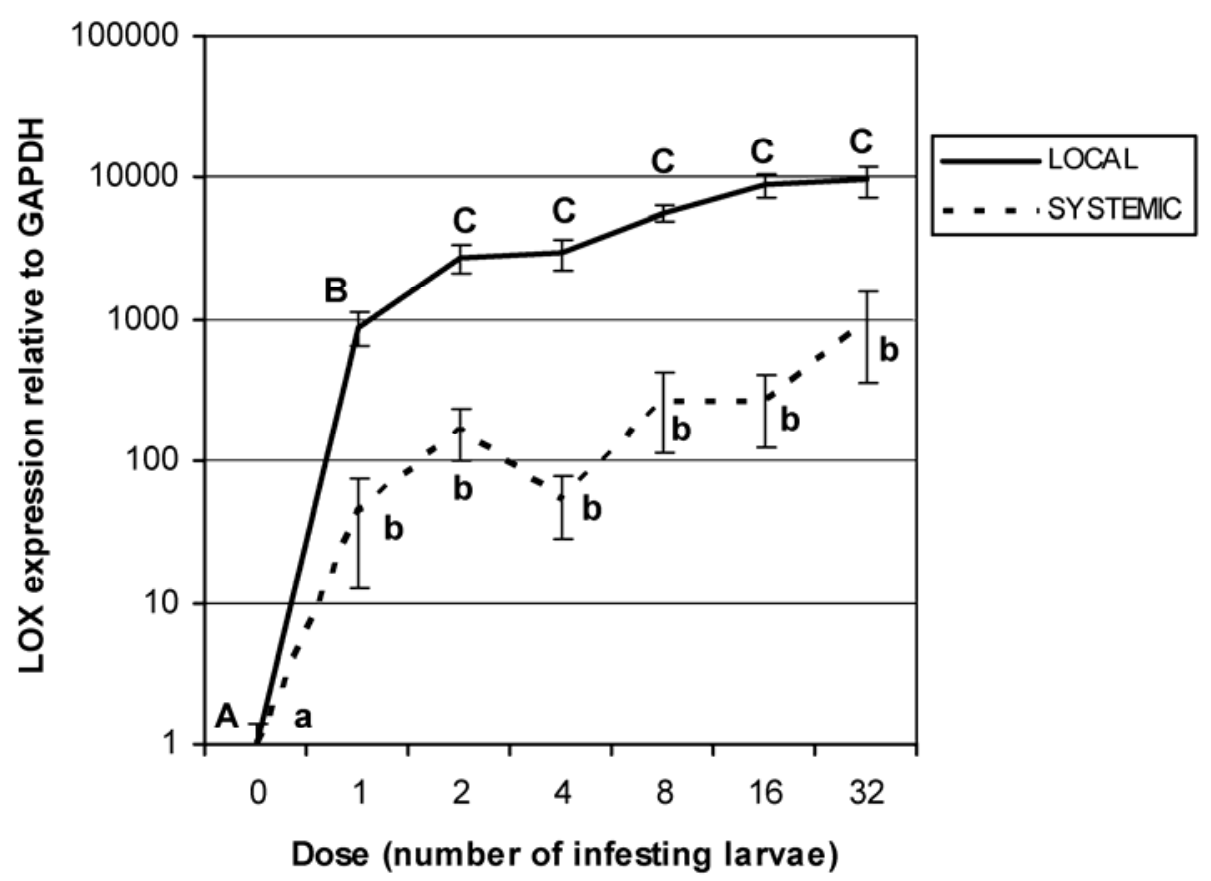

Fig. 6. Effect of caterpillar density of feeding on Brassica oleracea lipoxygenase (BoLOX) transcripts. A, Effect of number of first-instar Pieris brassicae or $P$. rapae larvae that infested a leaf on transcript levels of BoLOX (upper bands) and glyceraldehyde-3-phosphate dehydrogenase (GAPDH) (lower bands) genes as assessed by reverse-transcriptase polymerase chain reaction in local (L) and systemic (S) leaves. Numbers indicate the number of larvae that fed on the local leaf for $24 \mathrm{~h}$. The housekeeping gene GAPDH was used to indicate equal loading. B, Relative transcript levels of $B o L O X$ gene in local (L) and systemic (S) leaves after infestation of one first-instar P. rapae larva on the local leaf for $24 \mathrm{~h}$. Error bars indicate standard error of the mean $(n=3)$. Data points marked with different letters are significantly different (Kruskal-Wallis test, $\alpha=0.05$ ). 
tiles (Mattiacci et al. 2001; Scascighini et al. 2005; Steinberg et al. 1992). Therefore, BoLOX RNA accumulation was correlated with the dynamics in the early steps in the induction of defenses in B. oleracea in other studies.

\section{BoLOX transcript accumulation}

in response to herbivory and $\mathbf{J A}$.

We have extensively assessed the BoLOX transcript patterns with real-time quantitative PCR in response to different attackers and for different densities and different time points. These analyses show that $B o L O X$ transcripts are upregulated from undetectable levels in undamaged plants to high levels after herbivory by each of three different caterpillar species (the specialists Pieris rapae and $P$. brassicae and the generalist Mamestra brassicae), a locust (Schistocerca gregaria), a spider mite (Tetranychus urticae), and JA. It seems that the maximum transcript levels assessed after caterpillar feeding (up to 10,000-fold more than in the control) are higher than the levels recorded in response to locust and spider-mite damage. Mechanical wounding also increased BoLOX transcript levels, but to lower levels than after herbivory. However, mechanical wounding was applied in a single bout whereas herbivory continued for a period ranging from $1 \mathrm{~h}$ to 7 days depending on species and experiment. It would be interesting to investigate BoLOX RNA levels in response to mechanical damage that carefully simulated herbivory, such as with the MecWorm robot (Mithofer et al. 2005).

BoLOX transcripts are induced locally as well as systemically. The systemic response is weaker than the local response when the plant is damaged by caterpillars or locusts whereas the systemic response is stronger than the local response when the plant is infested with the bacterial pathogen Pseudomonas syringae. For caterpillar-induced defenses, this agrees with the finding that induced indirect defense occurs both locally (Steinberg et al. 1992) and systemically (Mattiacci et al. 2001). It should be noted that the systemic leaf in our study is the leaf directly under the infested leaf, whereas the systemic leaf in the study by Mattiacci et al. (2001) is the leaf above the infested leaf.
Dynamics of BoLOX RNA accumulation patterns.

The transcript levels of BoLOX are highly correlated with the applied JA concentration. Although its accumulation is also dependent on caterpillar density and herbivory duration, the increase in $B o L O X$ transcripts is restricted mainly to the lowest caterpillar densities and the shorter durations of herbivory. This corresponds well to the report that 3 to $72 \mathrm{~h}$ of feeding by five

\section{Spider mites}

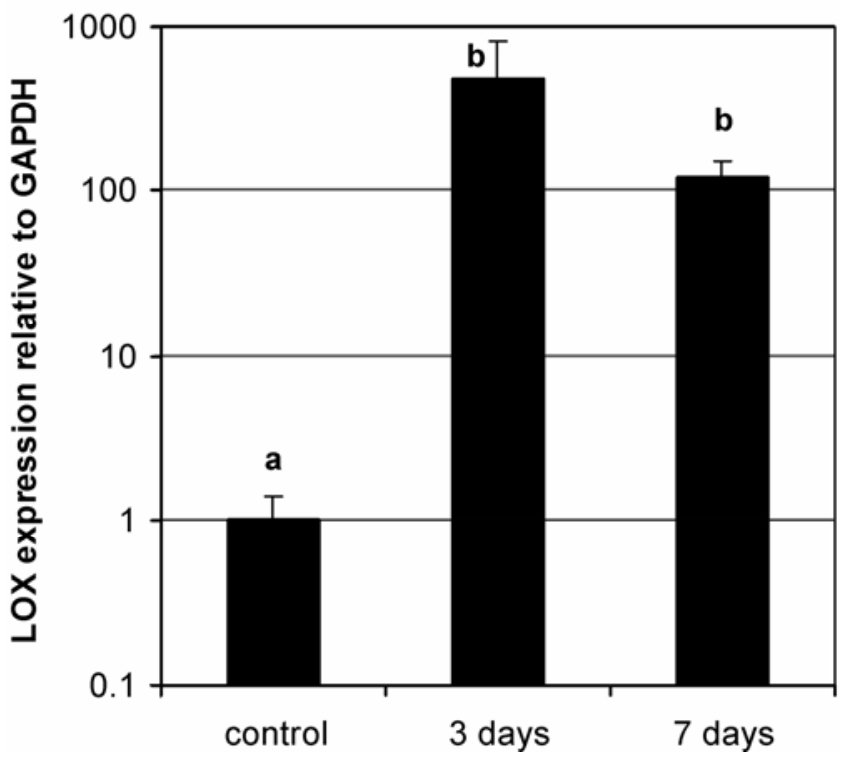

Fig. 8. Effect of spider mite infestation on Brassica oleracea lipoxygenase $(B o L O X)$ gene expression. Relative BoLOX transcript levels after spider mite infestation for 3 or 7 days. Error bars indicate standard error of the mean $(n=3)$. Data points marked with different letters are significantly different (Kruskal-Wallis test, $\alpha=0.05$ ).

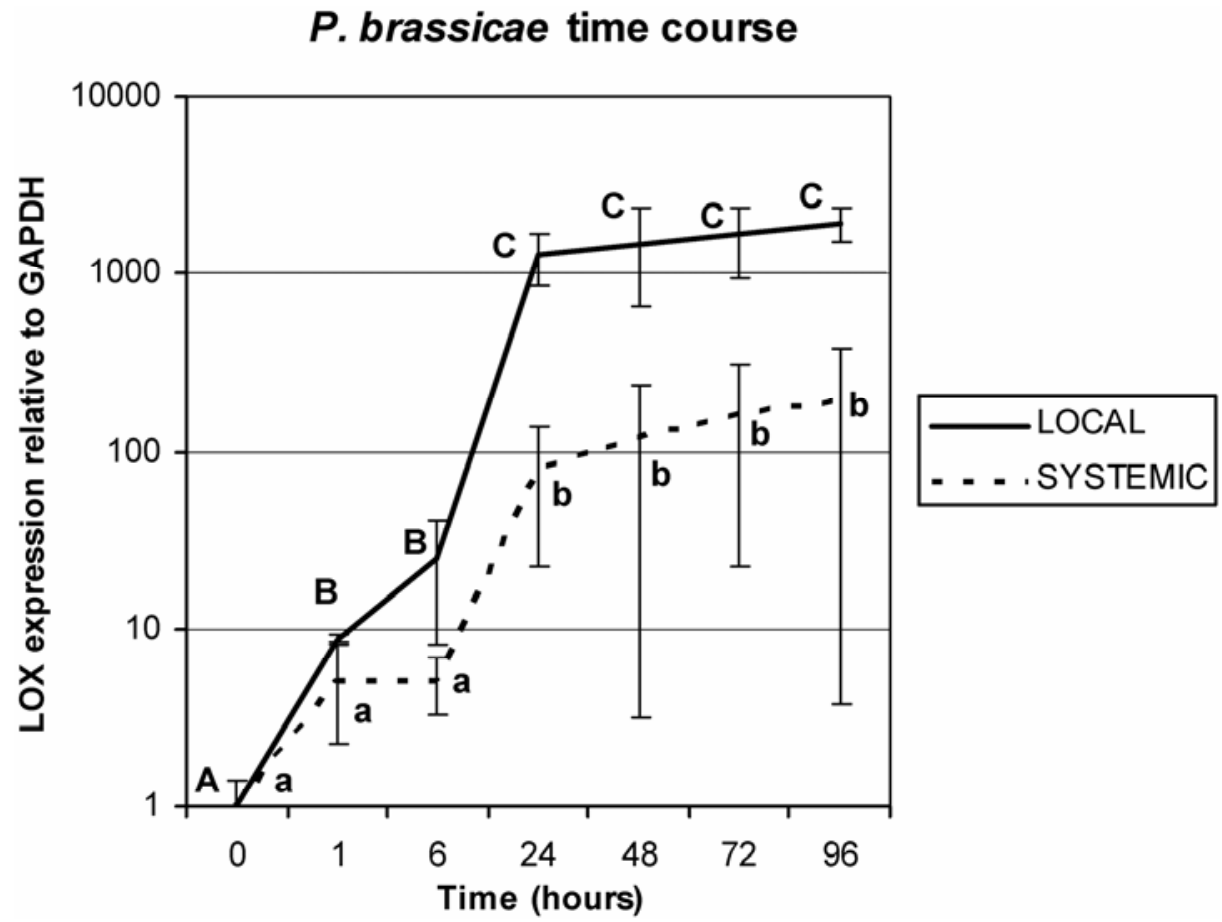

Fig. 7. Effect of caterpillar feeding time on Brassica oleracea lipoxygenase (BoLOX) transcript levels. Relative BoLOX transcript levels in local (L) and systemic (S) leaves after infestation of a local leaf with one first-instar Pieris brassicae larva during different time periods. Error bars indicate standard error of the mean $(n=3)$. Data points marked with different letters are significantly different (Kruskal-Wallis test, $\alpha=0.05$ ). 
first-instar Pieris rapae larvae induced a clear increase in JA levels in Arabidopsis (De Vos et al. 2005). Real-time quantitative PCR revealed that the fast increase in BoLOX transcript levels was induced by even a single Pieris caterpillar (i.e., already after $1 \mathrm{~h}$ of feeding). Although JA levels were not measured in
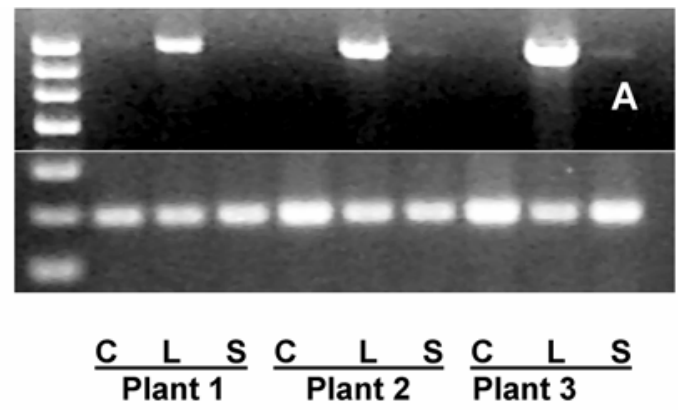

\section{B Mechanical damage for 3 days}

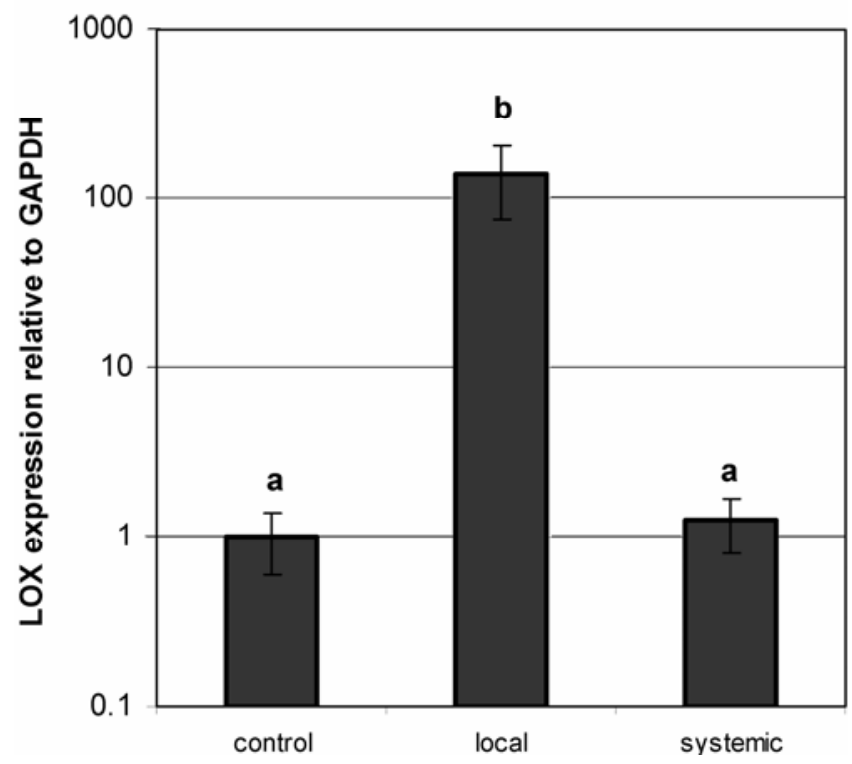

Fig. 9. Effect of mechanical wounding on Brassica oleracea lipoxygenase (BoLOX) gene expression in local (L) and systemic (S) leaves. A, BoLOX transcript levels in undamaged control plants (C), and in damaged local (L) and undamaged systemic (S) leaves of plants that had been mechanically damaged 3 days earlier. The housekeeping gene glyceraldehyde-3phosphate-dehydrogenase $(G A P D H)$ was used to indicate equal loading. Data for three independent replicate plants. B, Relative BoLOX transcripts 3 days after mechanical damage. Error bars indicate standard error of the mean $(n=3)$. Data points marked with different letters are significantly different (Kruskal-Wallis test, $\alpha=0.05$ ).
B. oleracea, by comparison with Arabidopsis and N. attenuata, it is presumed that this result may reflect the JA burst at the early stages of wounding (i.e., after $1 \mathrm{~h}$ in Arabidopsis [McConn et al. 1997] and 35 min in tobacco [Halitschke and Baldwin 2003]). The transcript level in both local and systemic leaves did not increase at caterpillar densities exceeding two first-instar larvae feeding for $24 \mathrm{~h}$. A period of $24 \mathrm{~h}$ of caterpillar feeding was needed to reach maximal transcript levels in both local and systemic leaves. During longer feeding duration, the expression level remained at the same level. This is comparable with the induction of potato LOX-HI (Royo et al. 1996). In contrast, potato $L O X-H 3$ and tobacco $N a L O X 3$ reach a maximum transcript level after 30 and $60 \mathrm{~min}$, respectively (Halitschke and Baldwin 2003; Royo et al. 1996).

It is remarkable that BoLOX transcript levels did not significantly increase when the caterpillar density increased from 2 to 32 per leaf. However, induced indirect defense of $B$. oleracea in response to Pieris caterpillars is highly density dependent. With increasing caterpillar density in the range of 1 to 90 firstinstar Pieris caterpillars, the relative attraction of parasitoids increases as well (Geervliet et al. 1998a). Within $24 \mathrm{~h}$ after the onset of caterpillar feeding, the BoLOX transcript level is increased to a limit value. The induction of indirect defense in $B$. oleracea in response to caterpillar feeding (50 second-instar $P$. brassicae caterpillars) also is known to increase within hours to a maximum value (Scascighini et al. 2005). Parasitic wasps that attack the caterpillars are increasingly attracted several hours after the start of herbivory; the main increase in volatile emission during the early hours because herbivory occurs in green leaf volatiles such as (Z)-3-hexenol and (Z)-3-hexen-1yl acetate (Scascighini et al. 2005) that are JA inducible (Dicke et al. 1999; Kessler and Baldwin 2001). The LOX concentration in the leaf may not be the limiting step after a certain transcript level has been reached. The amount of substrate, linolenic acid, is likely to determine the level of defense expression. Indeed, feeding of linolenic acid to plants induces defense expression (Koch et al. 1999).

BoLOX transcripts also were upregulated in response to infestation of the bacterial pathogen Pseudomonas syringae, but not in response to the aphid Myzus persicae. The aphids had been feeding for 7 days (i.e., much longer than, for instance, the caterpillars). Thus, the absence of $B o L O X$ transcripts indicates that the aphids did not induce this gene, which is confirmed in other B. oleracea genotypes (C. Broekgaarden, M. Dicke, and B. Vosman, unpublished data). It is interesting to note that the caterpillar Pieris rapae and the bacterium Pseudomonas syringae induce the biosynthesis of JA in Arabidopsis, whereas the aphid M. persicae does not (De Vos et al. 2005). This correlates with their effect on the transcript level of JA-responsive BoLOX, as reported here. However, the fact that a certain attacker induces JA does not imply that all JA-

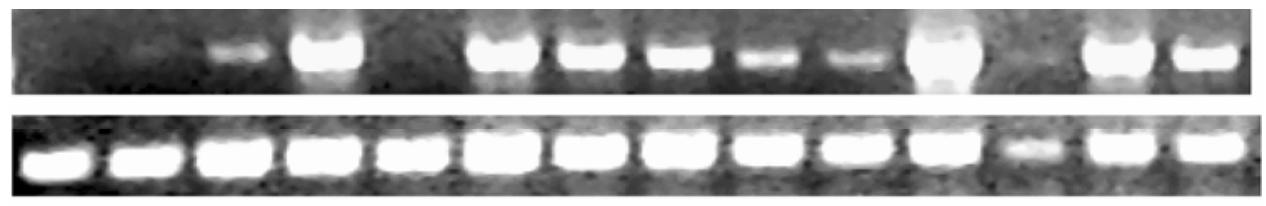

$$
\frac{\mathrm{L}}{\text { Control }} \frac{\mathrm{L}}{1 \mathrm{~h}} \frac{\mathrm{S}}{6 \mathrm{~h}} \quad \frac{\mathrm{L}}{24 \mathrm{~h}} \quad \frac{\mathrm{L}}{48 \mathrm{~h}} \quad \frac{\mathrm{L}}{72 \mathrm{~h}} \quad \frac{\mathrm{L}}{96 \mathrm{~h}}
$$

Fig. 10. Time course of Brassica oleracea lipoxygenase (BoLOX) and glyceraldehyde-3-phosphate dehydrogenase $(G A P D H)$ gene expression in pressureinfiltrated local leaves (L) and noninfiltrated systemic leaves (S) that were harvested at indicated time points after pathogen infiltration. Pressure infiltration was performed by infiltrating one fully expanded young leaf with a solution of $10 \mathrm{mM} \mathrm{MgSO}_{4}$ (control) or with a bacterium suspension of an optical density at $600 \mathrm{~nm}=0.1$ of virulent pathogen Pseudomonas syringae pv. tomato DC3000. In total, three experiments were performed on separate dates with similar results. The housekeeping gene $G A P D H$ was used to indicate equal loading. 
responsive genes are upregulated (De Vos et al. 2005). Crosstalk with other signaling pathways may modulate the effect of JA (Bostock 2005; De Vos et al. 2006; Thaler et al. 2002). In Arabidopsis, $P$. syringae does not induce AtLOX2 within $24 \mathrm{~h}$ when assessed with a full-genome microarray, despite the observation that $P$. syringae induces considerable increases in JA levels (De Vos et al. 2005). It will be interesting to investigate AtLOX2 expression with the much more sensitive method of real-time quantitative PCR.

\section{Induced defenses of $B$. oleracea.}

$B$. oleracea can be attacked by a range of arthropod herbivores, including caterpillars, aphids, grasshoppers, and beetles (Root 1973). Induced defenses of B. oleracea have been reported in response to aboveground and belowground herbivory (van Dam et al. 2004). Here, we have shown that BoLOX is upregulated in response to different herbivorous arthropods. The only herbivore that did not induce BoLOX RNA accumulation was the aphid $M$. persicae. These data correspond to data on JA induction by these herbivores in other plant species. The caterpillar Pieris rapae induces JA in Arabidopsis (De Vos et al. 2005) and the spider mite T. urticae induces JA in tomato and Lima bean plants (Engelberth et al. 2001; Kant et al. 2004), whereas the aphid M. persicae did not induce JA in Arabidopsis (De Vos et al. 2005).

A range of herbivores are known to induce defenses in Brassica spp., such as the cabbage root fly (Delia radicum) (van Dam and Raaijmakers 2006); the caterpillars Plutella xylostella (Lu et al. 2004; Vuorinen et al. 2004), Pieris rapae, P. napi, $P$. brassicae (Geervliet et al. 1996), and Mamestra brassicae (Geervliet et al. 1996); the flea beetle Phyllotreta cruciferae (Palaniswamy and Lamb 1993); and the leaf beetle Phaedon cochlearea (Rostas and Hilker 2002b). Different caterpillar species induce similar, though not identical, indirect defense in B. oleracea (Geervliet et al. 1996, 1998b). Moreover, pathogens also induce defenses in Brassica spp. (e.g., the bacterium Xanthomonas campestris [Pastuglia et al. 1997] or the fungi Alternaria brassicae [Rostas and Hilker 2002a, 2003] and Sclerotinia sclerotiorum [Li et al. 1999]).

Crosstalk between signaling pathways is well known to influence phenotype expression and, thus, the interaction between pathogens and herbivores (Stout et al. 2006). The phytopathogen Pseudomonas syringae induces the phytohormones JA, salicylic acid, and ethylene in Arabidopsis, and a subset of JAinducible genes are upregulated as a result (De Vos et al. 2005). In order to understand the plant-mediated interactions between phytopathogens and herbivorous insects, it is important to analyze the underlying mechanisms. For instance, investigating the mechanisms of Pieris rapae-induced resistance to phytopathogens unraveled new ways in which herbivorous insects influence plant-pathogen interactions, such as through priming of pathogen-inducible defense (De Vos et al. 2006).

\section{Conclusion.}

We have cloned a $B$. oleracea $L O X$ gene that likely is involved in JA biosynthesis, and quantified its transcript levels after various treatments and time intervals. Our data show that $B o L O X$ transcripts accumulate rapidly after various biotic stresses. The involvement of $B o L O X$ in mediating interactions between $B$. oleracea and its attackers will be further investigated in molecular ecological studies on multitrophic interactions.

\section{MATERIALS AND METHODS}

\section{Plants.}

Brussels sprouts (B. oleracea var. gemmifera cv. Cyrus) were grown in a greenhouse (50 to $70 \%$ relative humidity [RH], 20 to $30^{\circ} \mathrm{C}, 16: 8 \mathrm{~h} \mathrm{~L} / \mathrm{D}$ [h of light and darkness, respectively]). Morphologically uniform plants with six to eight leaves were used in all experiments (Fig. 4A). Plants were placed in a climate chamber $\left(70 \pm 10 \% \mathrm{RH}, 23 \pm 1{ }^{\circ} \mathrm{C}, 16: 8 \mathrm{~h} \mathrm{~L} / \mathrm{D}\right)$ for herbivore infestation or pathogen inoculation.

\section{Herbivores.}

Different herbivores were used in gene expression experiments. The caterpillars $P$. rapae (small cabbage white), $P$. brassicae (large cabbage white), and Mamestra brassicae (cabbage moth) were reared routinely on cabbage plants $(B$. oleracea var. gemmifera cv. Cyrus) at $21 \pm 1^{\circ} \mathrm{C}, 50$ to $70 \%$ $\mathrm{RH}, 16: 8 \mathrm{~h}$ L/D). Schistocerca gregaria (desert locust) was reared routinely on a mixture of rye, cabbage leaves, and grass at $33 \pm 2^{\circ} \mathrm{C}, 30$ to $40 \% \mathrm{RH}, 16: 8 \mathrm{~h} \mathrm{~L} / \mathrm{D}$. These herbivore species are leaf-chewing insects. Mesophyll-feeding T. urticae (twospotted spider mites) were reared on lima bean (Phaseolus lunatus) plants grown in a greenhouse (50 to $70 \% \mathrm{RH}, 20$ to $3^{\circ} \mathrm{C}, 16: 8 \mathrm{~h} \mathrm{~L} / \mathrm{D}$ ). Phloem-feeding Myzus persicae (green peach aphids) were maintained on B. chinensis L. cv. Granaat) in a greenhouse ( 50 to $70 \% \mathrm{RH}, 20$ to $30^{\circ} \mathrm{C}, 16: 8 \mathrm{~h} \mathrm{~L} / \mathrm{D}$ ). The $16-\mathrm{h}$ light period prevented sexual reproduction, keeping the aphid population clonal.

\section{Bacteria.}

The leaf pathogen Pseudomonas syringae pv. tomato DC3000 (Pieterse et al. 1996) was cultured in liquid King's medium B (King et al. 1954) at $28^{\circ} \mathrm{C}$. After we collected the cells by centrifugation, bacterial cells were resuspended in 10 $\mathrm{mM} \mathrm{MgSO}$ and adjusted to an optical density at $600 \mathrm{~nm}=0.1$ as described by Ryang and associates (2002).

\section{RNA isolation.}

Plants were subjected to different attackers for specified periods of time (discussed below). All harvested leaf material was directly frozen in liquid nitrogen, and stored at $-80^{\circ} \mathrm{C}$ for further RNA extraction.

Total RNA isolation from control and treated Brassica leaves was performed according to the method described by Zheng and associates (2005) with minor modifications. Briefly, $0.75 \mathrm{ml}$ of RNA extraction buffer $(100 \mathrm{mM}$ Tris pH8.5, $100 \mathrm{mM} \mathrm{NaCl}, 20 \mathrm{mM}$ EDTA, and 1\% Sarkosyl) with $\beta$-mercaptoethanol was added to each fine powder sample. An equal volume of phenol was added. After centrifugation, the aqueous phase was collected, and phenol/chloroform added followed by ethanol precipitation. The dried RNA pellet was dissolved by adding $50 \mu \mathrm{l}$ of DNase/RNase-free diethlpyrocarbonate-treated water. The concentration of RNA was measured with a BIO-RAD SmartSpec 3000.

\section{cDNA cloning of constitutive glyceraldehyde-3-phosphate- dehydrogenase and induced $B$ B LOX gene.}

First-strand cDNA was synthesized by following the manufacturer's protocol (Invitrogen, Leek, The Netherlands) and using $5 \mu \mathrm{g}$ of RNA from fully expanded leaves of $B$. oleracea plants that had been infested with Pieris rapae larvae for $24 \mathrm{~h}$ in a total volume of $40 \mu \mathrm{l}$. Degenerate primers for $L O X$ were designed from conserved regions of Arabidopsis thaliana AtLOX1 (Melan et al. 1993) and AtLOX2 (Bell and Mullet 1993), tomato TomLOXC and TomLOXD (Heitz et al. 1997), potato $\mathrm{H} 1$ ( $L O X 2)$ and H3 (LOX3) (Royo et al. 1996), tobacco LOX3 (Halitschke and Baldwin, 2003), and soybean LOX3 (Yenofsky et al. 1988): the forward primer used was 5'TDGCHGGHBTNAAYCC-3' and the reverse primer used was 5'-CTGTYGGATCYTCMGTTGGC-3'. Because GAPDH was proven to be a good housekeeping gene in sugarcane (Iskandar et al. 2004), is active in all mammalian tissues, and 
frequently is used as housekeeping gene in expression studies (Carraro et al. 2005), degenerate primers for GAPDH were designed from DNA sequence alignment of GAPDH sequences from several monocot and dicot species available in GenBank: forward primer 5'-AGRAACCCTGARGADATYCCRTGGG$3^{\prime}$ and reverse primer 5'-CCAGCCTTGGCRTCRAARATGC T-3'. PCR was performed in a total of $50 \mu \mathrm{l}$ containing $0.2 \mu \mathrm{M}$ primers, $0.2 \mathrm{mM}$ dNTPs, 0.4 units of Super Taq DNA polymerase (Invitrogen), $1 \times$ PCR buffer (Invitrogen), and $2 \mu \mathrm{l}$ of first-strand cDNA. Temperature programs were: $2 \mathrm{~min}$ at $94^{\circ} \mathrm{C}$; 40 cycles of $1 \mathrm{~min}$ at $94^{\circ} \mathrm{C}, 1 \mathrm{~min}$ at $45^{\circ} \mathrm{C}$, and $1 \mathrm{~min}$ at $72^{\circ} \mathrm{C}$; and $10 \mathrm{~min}$ at $72^{\circ} \mathrm{C}$. The purification, ligation, and bacterial transformation of the PCR products was done according to the manufacturer's protocol. Ampicillin-resistant colonies were identified and plasmid DNA was isolated using a miniprep kit (Qiagen, Venlo, The Netherlands) according to the manufacturer's instructions. Plasmids were selected which showed inserts of the expected size after digestion with $N c o$ I and SalI. Expected inserts based on size were used for sequencing. Sequencing was performed in an ABI PRISM 310 automated DNA sequencer (Perkin Elmer, Foster City, CA, U.S.A.).

\section{5'- and $3^{\prime}$-RACE of induced $L O X$ gene.}

Cloning of $5^{\prime}$ and $3^{\prime}$ ends of the inducible $L O X$ gene was accomplished by RACE using the BD SMART RACE cDNA Amplification Kit (BD Bioscience Clontech, Palo Alto, CA, U.S.A.) following the manufacturer's protocol. 3'-RACEReady cDNA and 5'-RACE-Ready cDNA were synthesized from $1 \mu \mathrm{g}$ pf RNA from $P$. rapae-infested leaves. BoLOX genespecific primers were designed based upon the abovementioned partial sequence. The criteria for these gene specific primers were 23 to 28 nucleotide, 50 to $70 \% \mathrm{GC}$, and temperature $>70^{\circ} \mathrm{C}$, enabling the use of touchdown PCR. The forward gene-specific primer is GSF1: 5'-GGAGTGGTCCACAGTCA AGGGCACTG-3' and reverse gene-specific primer is GSR1: 5'-CCCCCTGCTGATGAGGTCTGCAGGTA-3'. The genespecific primers designed here produced overlapping 1,030-bp products. For 5'-RACE or 3'-RACE, a total volume of $50 \mu \mathrm{l}$ was used in the PCR reaction and touchdown PCR was performed for $2 \mathrm{~min}$ at $94^{\circ} \mathrm{C} ; 5$ cycles of $30 \mathrm{~s}$ at $94^{\circ} \mathrm{C}$ and $3 \mathrm{~min}$ at $72^{\circ} \mathrm{C} ; 5$ cycles of $30 \mathrm{~s}$ at $94^{\circ} \mathrm{C}, 30 \mathrm{~s}$ at $70^{\circ} \mathrm{C}$, and $3 \mathrm{~min}$ at $72^{\circ} \mathrm{C}$; and 25 cycles of $30 \mathrm{~s}$ at $94^{\circ} \mathrm{C}, 30 \mathrm{~s}$ at $68^{\circ} \mathrm{C}$, and $3 \mathrm{~min}$ at $72^{\circ} \mathrm{C}$ based on the recommended protocol. The $5^{\prime}-$ and $3^{\prime}-$ RACE products were purified, ligated into pGEM-T vector (Promega Corp., Madison, WI, U.S.A.), and sequenced as explained above.

\section{Sequence analysis.}

For sequence analysis we used the Vector NTI software (Advance 9.1; Invitrogen, life science software). For contig building, the CAP3 Sequence Assembly Program was used (Huang and Madan 1999). Sequence relatedness was analyzed using ClustalX 1.83 using the neighbor-joining method, and visualized using TreeView. Subcellular localization prediction for protein was performed with the iPSORT prediction program.

\section{Reverse transcription followed by quantitative real-time PCR (real-time RT-PCR) for gene expression.}

All RNA samples (10 $\mu \mathrm{g}$ of total RNA) were treated with 1 $\mu l$ of RQ1 RNase-free DNase (Promega Corp.) with $1 \times$ DNase buffer in a total volume of $50 \mu \mathrm{l}$ at $37^{\circ} \mathrm{C}$ for $10 \mathrm{~min}$ to remove genomic DNA. The samples were purified by extraction with equal volumes of phenol/chloroform and chloroform followed by ethanol precipitation as described for the RNA isolation. After purification, the RNA concentration was measured again using a NanoDropND-100 spectrophotometer. The iScript cDNA Synthesis Kit (Bio-Rad, Hercules, CA, U.S.A.) was used for synthesis of cDNA from $1 \mu \mathrm{g}$ of total RNA in a total volume of $20 \mu \mathrm{l}$. The reaction was incubated at $25^{\circ} \mathrm{C}$ for $5 \mathrm{~min}$ and $42^{\circ} \mathrm{C}$ for $30 \mathrm{~min}$. The reaction was stopped by incubating at $85^{\circ} \mathrm{C}$ for $5 \mathrm{~min}$. Then, $80 \mu \mathrm{l}$ of water was added to each sample to make the final $100 \mu \mathrm{l}$ of cDNA solution. The genespecific primers of $B O L O X$ and GAPDH were designed with the Beacon Designer software (Premier Biosoft International, Palo Alto, CA, U.S.A.) set to an annealing temperature of $60^{\circ} \mathrm{C}$. BoLOX primers were F-BoLOX (5'-ACTTTCCCGTCC CGTTCTTGG-3') and R-BoLOX (5'-GATTGTCGTGCCCGT GAATGC-3'). Its predicted length was $175 \mathrm{bp}$. GAPDH primers were F-GAPDH (5'-GCTACGCAGAAGACAGTTGATGG-3') and R-GAPDH (5'-TGGGCACACGGAAGGACATAC-3'). Its predicted length was $163 \mathrm{bp}$. These primer sequences were blasted against the National Center for Biotechnology Information nucleotide and expressed sequence tag database to ascertain that they are not homologous to other genes. Several primer concentrations ranging from 200 to $800 \mathrm{nM}$ were used to determine the optimal primer concentrations; $400 \mathrm{nM}$ for both F-BoLOX and R-BoLOX and $800 \mathrm{nM}$ for both F-GAPDH and R-GAPDH were optimal. For PCR amplification efficiency, gradient annealing temperatures from 56 to $66^{\circ} \mathrm{C}$ were checked in advance. This resulted in the selection of $56^{\circ} \mathrm{C}$ as the optimal annealing temperature for both PCRs. One sample was chosen for making a five-log dilution series, on the basis of highest expected BoLOX transcript level. In each 96-well plate, this dilution series was included. The RT-PCR analyses of reference and target gene transcripts in cDNA samples were conducted in the iCycler IQ real-time PCR detection system (Bio-Rad). A 25- $\mu$ l PCR reaction was prepared containing $1 \mu \mathrm{l}$ of template cDNA, $1 \mu \mathrm{l}$ each of forward and reverse primer, $9.5 \mu \mathrm{l}$ of water, and $12.5 \mu \mathrm{l}$ of $2 \times$ iQ SYBR green Supermix (Bid-Rad). The final amount of cDNA template assayed was equivalent to $10 \mathrm{ng}$ of RNA. All samples were amplified in duplicate assays under the following conditions: $95^{\circ} \mathrm{C}$ for 3 min for 1 cycle, followed by 40 cycles of $95^{\circ} \mathrm{C}$ for $15 \mathrm{~s}$ and 45 $\mathrm{s}$ at $56^{\circ} \mathrm{C}$, with data collection at $56^{\circ} \mathrm{C}$. The PCR products for each primer set also were subjected to melt-curve analysis. The melt-curve analysis ensured that the resulting fluorescence originated from a single PCR product and did not represent primer dimers formed during the PCR or nonspecific product. No-template control as water and minus RT (10 ng of RNA) also were included to detect any spurious signals arising from amplification of any DNA contamination or primer dimer formed during the reaction. Direct detection of the PCR product was measured by monitoring the increase in fluorescence caused by the binding of the SYBR green dye to doublestranded DNA. The BoLOX expression relative to GAPDH expression was quantified by comparing the threshold cycle for each PCR to their respective dilution series and dividing the resulting quantities. The $B o L O X / G A P D H$ ratios for all samples were related to the ratio for untreated plants, which was set to 1. The mean efficiencies and standard errors of the means of the PCRs were $94.8 \pm 1.6 \%$ for $B o L O X$ and $97.6 \pm 2.3 \%$ for GAPDH, based on the dilution series in eight PCR runs.

Quantitative RT-PCR data were analyzed with the KruskalWallis test $(\alpha=0.05)$.

\section{Analysis of BoLOX transcript patterns.}

For a few experiments, RT-PCR was carried out. First-strand cDNA was synthesized as mentioned above. The PCR program used for gene expression was 2 min at $94^{\circ} \mathrm{C} ; 5$ cycles of $30 \mathrm{~s}$ at $94^{\circ} \mathrm{C}$ and $3 \mathrm{~min}$ at $72^{\circ} \mathrm{C} ; 5$ cycles of $30 \mathrm{~s}$ at $94^{\circ} \mathrm{C}, 30 \mathrm{~s}$ at $70^{\circ} \mathrm{C}$, and $3 \mathrm{~min}$ at $72^{\circ} \mathrm{C}$; and 15 cycles of $30 \mathrm{~s}$ at $94^{\circ} \mathrm{C}, 30 \mathrm{~s}$ at $68^{\circ} \mathrm{C}$, and $3 \mathrm{~min}$ at $72^{\circ} \mathrm{C}$. The gene-specific primers GSF1 and GSR1 produced 1,030-bp products. Touchdown PCR also was used for the housekeeping gene $G A P D H$ as loading control. 
The PCR program was $2 \mathrm{~min}$ at $94^{\circ} \mathrm{C} ; 5$ cycles of $30 \mathrm{~s}$ at $94^{\circ} \mathrm{C}$ and $3 \mathrm{~min}$ at $72^{\circ} \mathrm{C} ; 5$ cycles of $30 \mathrm{~s}$ at $94^{\circ} \mathrm{C}, 30 \mathrm{~s}$ at $70^{\circ} \mathrm{C}$, and $3 \mathrm{~min}$ at $72^{\circ} \mathrm{C}$; and 10 cycles of $30 \mathrm{~s}$ at $94^{\circ} \mathrm{C}, 30 \mathrm{~s}$ at $68^{\circ} \mathrm{C}$, and $3 \mathrm{~min}$ at $72^{\circ} \mathrm{C}$. $\mathrm{GAPDH}$-specific primers (forward primer: $5^{\prime}$ CACTGACAAGGACAAGGCTGCTGCT-3'; reverse primer: 5'-CGGCTCTTCCACCTCTCCAGTCCTTC-3') produced 299bp products. For the following gene-expression experiments, local and systemic leaf definition, number of replications per treatment, sampling, RNA isolation, first-strand cDNA synthesis, and PCR conditions were the same as mentioned above unless otherwise specified.

Different densities of $\boldsymbol{P}$. rapae and $\boldsymbol{P}$. brassicae caterpillars.

To investigate $B o L O X$ transcript levels in cabbage plants that had been subjected to different caterpillar numbers, 1, 2, 4, 8, 16 , or 32 first-instar larvae of $P$. rapae or $P$. brassicae were used to infest one of the youngest fully expanded leaves for $24 \mathrm{~h}$. Control plants were placed in the same climate chamber without contact with caterpillars. Care was taken to avoid wounding of plants during transfer of larvae to the plants. There were at least three replicate plants for each dose treatment. The infested and damaged youngest, fully expanded leaf was denoted as local leaf, while one undamaged leaf directly below the infested leaf was denoted as systemic leaf. Before sampling, we checked that the larvae were still feeding on the leaf on which they had been released. In most cases, caterpillars had stayed on the initial leaf; otherwise, the plant was discarded. Subsequently, the larvae were removed from the local leaf and the leaf was cleaned with wet tissue.

\section{Different periods of feeding}

\section{by $P$. rapae, $P$. brassicae, or $M$. brassicae caterpillars.}

Cabbage plants were infested with a single first-instar larva of either $P$. rapae or $P$. brassicae on one of youngest fully expanded leaves for $1,6,24,48,72$, or $96 \mathrm{~h}$. Control plants were placed in the same climate chamber without contact with caterpillars. The same was done for a single caterpillar of $M$. brassicae and, here, infestation lasted $72 \mathrm{~h}$ or 7 days.

\section{Infestation with $S$. gregaria.}

One first-instar $S$. gregaria locust was transferred onto a cabbage plant placed in a cage. One plant was placed in each cage. A control plant also was placed into a cage in the same climate chamber without contact with $S$. gregaria. One of the youngest fully expanded leaves that received locust feeding was denoted as local leaf. The leaf below this local leaf had been covered with a plastic bag to prevent locust feeding and this undamaged leaf was denoted as systemic leaf. The infestation lasted for $72 \mathrm{~h}$.

\section{Infestation with $T$. urticae.}

Adult female two-spotted spider mites were transferred to cabbage plants. Lima bean leaves with more than 50 adult female of spider mites were placed on a leaf of each cabbage plant. After the spider mites had moved onto the cabbage plant for 3 to $4 \mathrm{~h}$, the lima bean leaves were removed. One of the youngest fully expanded leaves that had received visible spider mite damage was sampled 72 or $168 \mathrm{~h}$ after introduction of the mites. The mites were removed before sampling. Control plants were placed in the same climate chamber without contact with spider mites. Local and systemic leaves were not separated because spider mites distributed over the whole plant.

\section{Infestation by Myzus persicae.}

Cabbage plants were infested with Myzus persicae aphids by carefully transferring 40 nymphs and apterous adults to each plant with a fine brush. Infested and control plants were placed in a climate chamber for 7 days. Because $M$. persicae reproduce asexually and produce larvae very quickly, they attained high densities on the whole plant, especially on young leaves, causing water stress, wilting, and reduced growth rate of the plant after 7 days of infestation (Fig. 4F and G). A fully expanded young leaf was sampled after the aphids had been feeding for 7 days and aphids were removed before sampling.

\section{Mechanical wounding and treatment of plants with the phytohormone JA.}

A cabbage plant was mechanically wounded by making 2.5 $\mathrm{cm}$-diameter punches in the fully expanded young leaves using a cork borer. Two leaves were damaged and three punches were made in each of these leaves. The six punches were collected from each plant and the material was immediately frozen in liquid nitrogen and treated as control for this plant. At 1, 6,24 , and $72 \mathrm{~h}$ after wounding the leaves, damaged leaves and one leaf just below the damaged leaves were sampled as local and systemic leaves, respectively.

Intact plants were sprayed with $20 \mathrm{ml}$ of an aqueous solution of the phytohormone JA (Sigma, St. Louis) at concentrations of 10,100 , and $1,000 \mu \mathrm{M}$ JA. The solutions contained $0.1 \%$ Tween 20 . Control plants were sprayed with $20 \mathrm{ml}$ of water containing $0.1 \%$ Tween 20 . All plants were maintained in a climate chamber for $24 \mathrm{~h}$.

\section{Inoculation of bacterial pathogen Pseudomonas syringae.}

One fully expanded young cabbage leaf per plant was inoculated with the bacterial suspension by syringe infiltration as described by (Ryang et al. 2002). This pressure-infiltrated leaf was denoted as local leaf and one untreated leaf just below this local leaf was designated as systemic leaf. Mock inoculations were performed with $10 \mathrm{mM} \mathrm{MgSO}_{4}$ in control plants. The local leaf was covered with a plastic bag to maintain $100 \% \mathrm{RH}$. Plants were incubated in a climate chamber $\left(70 \% \mathrm{RH}, 23^{\circ} \mathrm{C}\right.$, 16:8 h L/D). After 1, 6, 24, 48, 72, and $96 \mathrm{~h}$, the leaf samples were harvested.

\section{ACKNOWLEDGMENTS}

This work was financially supported by a VICI grant from the Netherlands Organisation for Scientific Research, NWO (865.03.002) to M. Dicke. We thank L. Koopman, F. van Aggelen, and A. Gidding for insect rearing and Unifarm of Wageningen University for the supply of cabbage plants. C. Pieterse (Utrecht University) kindly provided a starting colony of Pseudomonas syringae pv. tomato DC3000. The insightful comments of three anonymous referees and L. L. Walling are gratefully acknowledged; they have helped to significantly improve an earlier version of the manuscript.

\section{LITERATURE CITED}

Agrawal, A. A. 2000. Benefits and costs of induced plant defense for Lepidium virginicum (Brassicaceae). Ecology 81:1804-1813.

Barth, C., and Jander, G. 2006. Arabidopsis myrosinases TGG1 and TGG2 have redundant function in glucosinolate breakdown and insect defense. Plant J. 46:549-562.

Bell, E., and Mullet, J. E. 1993. Characterization of an Arabidopsis lipoxygenase gene responsive to methyl jasmonate and wounding. Plant Physiol. 103:1133-1137.

Bell, E., Creelman, R. A., and Mullet, J. E. 1995. A chloroplast lipoxygenase is required for wound-induced jasmonic acid accumulation in Arabidopsis. Proc. Natl. Acad. Sci. U.S.A. 92:8675-8679.

Bostock, R. M. 2005. Signal crosstalk and induced resistance: Straddling the line between cost and benefit. Annu. Rev. Phytopathol. 43:545-580.

Bruinsma, M., van Dam, N. M., van Loon, J. J. A., and Dicke, M. 2007. Jasmonic acid-induced changes in Brassica oleracea affect oviposition preference of two specialist herbivores. J. Chem. Ecol. 33:655-668.

Carraro, G., Albertin, G., Forneris, M., and Nussdorfer, G. G. 2005. Similar sequence-free amplification of human glyceraldehyde-3-phosphate dehydrogenase for real time RT-PCR applications. Mol. Cell. Probes 19:181-186. 
De Vos, M., Van Oosten, V. R., Van Poecke, R. M. P., Van Pelt, J. A., Pozo, M. J., Mueller, M. J., Buchala, A. J., Metraux, J. P., Van Loon, L. C., Dicke, M., and Pieterse, C. M. J. 2005. Signal signature and transcriptome changes of Arabidopsis during pathogen and insect attack. Mol. Plant-Microbe Interact. 18:923-937.

De Vos, M., Van Zaanen, W., Koornneef, A., Korzelius, J. P., Dicke, M., Van Loon, L. C., and Pieterse, C. M. J. 2006. Herbivore-induced resistance against microbial pathogens in Arabidopsis. Plant Physiol. $142: 352-363$

Dicke, M., and Van Poecke, R. M. P. 2002. Signalling in plant-insect interactions: Signal transduction in direct and indirect plant defense. Pages 289-316 in: Plant Signal Transduction. D. Scheel and C. Wasternack, eds. Oxford University Press, Oxford.

Dicke, M., Gols, R., Ludeking, D., and Posthumus, M. A. 1999. Jasmonic acid and herbivory differentially induce carnivore-attracting plant volatiles in lima bean plants. J. Chem. Ecol. 25:1907-1922.

Dicke, M., van Poecke, R. M. P., and de Boer, J. G. 2003. Inducible indirect defense of plants: From mechanisms to ecological functions. Basic Appl. Ecol. 4:27-42.

Engelberth, J., Koch, T., Schuler, G., Bachmann, N., Rechtenbach, J., and Boland, W. 2001. Ion channel-forming alamethicin is a potent elicitor of volatile biosynthesis and tendril coiling. Cross talk between jasmonate and salicylate signaling in lima bean. Plant Physiol. 125:369-377.

Farmaki, T., Sanmartin, M., Jimenez, P., Paneque, M., Sanz, C., Vancanneyt, G., Leon, J., and Sanchez-Serrano, J. J. 2007. Differential distribution of the lipoxygenase pathway enzymes within potato chloroplasts. J. Exp. Bot. 58:555-568.

Feussner, I., and Wasternack, C. 2002. The lipoxygenase pathway. Annu. Rev. Plant Biol. 53:275-297.

Geervliet, J. B. F., Vet, L. E. M., and Dicke, M. 1996. Innate responses of the parasitoids Cotesia glomerata and C. rubecula (Hymenoptera: Braconidae) to volatiles from different plant-herbivore complexes. J. Insect Behav. 9:525-538.

Geervliet, J. B. F., Ariens, S., Dicke, M., and Vet, L. E. M. 1998a. Longdistance assessment of patch profitability through volatile infochemicals by the parasitoids Cotesia glomerata and C. rubecula (Hymenoptera: Braconidae). Biol. Control 11:113-121.

Geervliet, J. B. F., Vreugdenhil, A. I., Vet, L. E. M., and Dicke, M. 1998 b. Learning to discriminate between infochemicals from different planthost complexes by the parasitoids Cotesia glomerata and C. rubecula (Hymenoptera: Braconidae). Entomol. Exp. Appl. 86:241-252.

Gols, R., Bukovinszky, T., Hemerik, L., Harvey, J. A., Van Lenteren, J. C., and Vet, L. E. M. 2005. Reduced foraging efficiency of a parasitoid under habitat complexity: Implications for population stability and species coexistence. J. Anim. Ecol. 74:1059-1068.

Halitschke, R., and Baldwin, I. T. 2003. Antisense LOX expression increases herbivore performance by decreasing defense responses and inhibiting growth-related transcriptional reorganization in Nicotiana attenuata. Plant J. 36:794-807.

Halitschke, R., Ziegler, J., Keinanen, M., and Baldwin, I. T. 2004. Silencing of hydroperoxide lyase and allene oxide synthase reveals substrate and defense signaling crosstalk in Nicotiana attenuata. Plant J. 40:3546.

Harvey, J. A., van Dam, N. M., and Gols, R. 2003. Interactions over four trophic levels: Food plant quality affects development of a hyperparasitoid as mediated through a herbivore and its primary parasitoid. J. Anim. Ecol. 72:520-531.

Heitz, T., Bergey, D. R., and Ryan, C. A. 1997. A gene encoding a chloroplast-targeted lipoxygenase in tomato leaves is transiently induced by wounding, systemin, and methyl jasmonate. Plant Physiol. 114:10851093.

Huang, X., and Madan, A. 1999. CAP3: A DNA sequence assembly program. Genome Res. 9:868-877.

Iskandar, H. M., Simpson, R. S., Casu, R. E., Bonnett, G. D., Maclean, D. J., and Manners, J. M. 2004. Comparison of reference genes for quantitative real-time polymerase chain reaction analysis of gene expression. Plant Mol. Biol. Rep. 22:325-337.

Jander, G., Cui, J. P., Nhan, B., Pierce, N. E., and Ausubel, F. M. 2001. The TASTY locus on chromosome 1 of Arabidopsis affects feeding of the insect herbivore Trichoplusia ni. Plant Physiol. 126:890-898.

Kahl, J., Siemens, D. H., Aerts, R. J., Gäbler, R., Kühnemann, F., Preston, C. A., and Baldwin, I. T. 2000. Herbivore-induced ethylene suppresses a direct defense but not a putative indirect defense against an adapted herbivore. Planta 210:336-342.

Kant, M. R., Ament, K., Sabelis, M. W., Haring, M. A., and Schuurink, R. C. 2004. Differential timing of spider mite-induced direct and indirect defenses in tomato plants. Plant Physiol. 135:483-495.

Karban, R., and Baldwin, I. T. 1997. Induced Responses to Herbivory. Chicago University Press, Chicago.

Kessler, A., and Baldwin, I. T. 2001. Defensive function of herbivore- induced plant volatile emissions in nature. Science 291:2141-2144.

Kessler, A., and Baldwin, I. T. 2002. Plant responses to insect herbivory: The emerging molecular analysis. Annu. Rev. Plant Biol. 53:299-328.

Kessler, A., Halitschke, R., and Baldwin, I. T. 2004. Silencing the jasmonate cascade: Induced plant defenses and insect populations. Science 305:665-668.

King, E. O., Ward, M. K., and Raney, D. E. 1954. Two simple media for the demonstration of pyocyanin and fluorescin. J. Lab. Clin. Med. 44:301-307.

Koch, T., Krumm, T., Jung, V., Engelberth, J., and Boland, W. 1999. Differential induction of plant volatile biosynthesis in the lima bean by early and late intermediates of the octadecanoid signaling pathway. Plant Physiol. 121:153-162.

Lee, H. S., Wang, J. L., Tian, L., Jiang, H. M., Black, M. A., Madlung, A., Watson, B., Lukens, L., Pires, J. C., Wang, J. J., Comai, L., Osborn, T. C., Doerge, R. W., and Chen, Z. J. 2004. Sensitivity of 70-mer oligonucleotides and cDNAs for microarray analysis of gene expression in Arabidopsis and its related species. Plant Biotechnol. J. 2:45-57.

Li, Y., Kiddle, G., Bennett, R. N., and Wallsgrove, R. M. 1999. Local and systemic changes in glucosinolates in Chinese and European cultivars of oilseed rape (Brassica napus L.) after inoculation with Sclerotinia sclerotiorum (stem rot). Ann. Appl. Biol. 134:45-58

Louda, S. M., and Rodman, J. E. 1996. Insect herbivory as a major factor in the shade distribution of a native crucifer (Cardamine cordifolia A. Gray, bittercress). J. Ecol. 84:229-237.

Lu, Y. B., Liu, S. S., Liu, Y. Q., Furlong, M. J., and Zalucki, M. P. 2004. Contrary effects of jasmonate treatment of two closely related plant species on attraction of and oviposition by a specialist herbivore. Ecol. Lett. 7:337-345.

Mattiacci, L., Dicke, M., and Posthumus, M. A. 1995. beta-Glucosidase: An elicitor of herbivore-induced plant odor that attracts host-searching parasitic wasps. Proc. Natl. Acad. Sci. U.S.A. 92:2036-2040.

Mattiacci, L., Rudelli, S., Rocca, B. A., Genini, S., and Dorn, S. 2001. Systemically-induced response of cabbage plants against a specialist herbivore, Pieris brassicae. Chemoecology 11:167-173.

Mauricio, R. 1998. Costs of resistance to natural enemies in field populations of the annual plant Arabidopsis thaliana. Am. Nat. 151:20-28.

Mauricio, R., and Rausher, M. D. 1997. Experimental manipulation of putative selective agents provides evidence for the role of natural enemies in the evolution of plant defense. Evolution 5:1435-1444.

Mauricio, R., Rausher, M. D., and Burdick, D. S. 1997. Variation in the defense strategies of plants: Are resistance and tolerance mutually exclusive? Ecology 78:1301-1311.

McConn, M., Creelman, R. A., Bell, E., Mullet, J. E., and Browse, J. 1997. Jasmonate is essential for insect defense Arabidopsis. Proc. Natl. Acad. Sci. U.S.A. 94:5473-5477.

Melan, M. A., Dong, X., Endara, M. E., Davis, K. R., Ausubel, F. M., and Peterman, T. K. 1993. An Arabidopsis thaliana lipoxygenase gene can be induced by pathogens, abscisic acid, and methyl jasmonate. Plant Physiol. 101:441-450.

Mitchell-Olds, T. 2001. Arabidopsis thaliana and its wild relatives: A model system for ecology and evolution. Trends Ecol. Evol. 16:693-700.

Mithofer, A., Wanner, G., and Boland, W. 2005. Effects of feeding Spodoptera littoralis on lima bean leaves. II. Continuous mechanical wounding resembling insect feeding is sufficient to elicit herbivoryrelated volatile emission. Plant Physiol. 137:1160-1168.

Mornhinweg, D. W., Brewer, M. J and Porter, D. R. 2006. Effect of Russian wheat aphid on yield and yield components of field grown susceptible and resistant spring barley. Crop Sci. 46:36-42.

Moyes, C. L., and Raybould, A. F. 2001. The role of spatial scale and intraspecific variation in secondary chemistry in host-plant location by Ceutorhynchus assimilis (Coleoptera:Curculionidae). Proc. R. Soc. Lond. Ser. B Biol. Sci. 268:1567-1573.

Moyes, C. L., Collin, H. A., Britton, G., and Raybould, A. E. 2000. Glucosinolates and differential herbivory in wild populations of Brassica oleracea. J. Chem. Ecol. 26:2625-2641.

Nemchenko, A., Kunze, S., Feussner, I., and Kolomiets, M. 2006. Duplicate maize 13-lipoxygenase genes are differentially regulated by circadian rhythm, cold stress, wounding, pathogen infection, and hormonal treatments. J. Exp. Bot. 57:3767-3779.

Nielsen, J. K., and de Jong, P. W. 2005. Temporal and host-related variation in frequencies of genes that enable Phyllotreta nemorum to utilize a novel host plant, Barbarea vulgaris. Entomol. Exp. Appl. 115:265-270.

Palaniswamy, P., and Lamb, R. J. 1993. Wound-induced antixenotic resistance to flea beetles, Phyllotreta cruciferae (Goeze) (Coleoptera, Chrysomelidae), in crucifers. Can. Entomol. 125:903-912.

Park, J. H., Halitschke, R., Kim, H. B., Baldwin, I. T., Feldmann, K. A., and Feyereisen, R. 2002. A knock-out mutation in allene oxide synthase results in male sterility and defective wound signal transduction in Arabidopsis due to a block in jasmonic acid biosynthesis. Plant J. 31:1-12. 
Pastuglia, M., Roby, D., Dumas, C., and Cock, J. M. 1997. Rapid induction by wounding and bacterial infection of an $\mathrm{S}$ gene family receptorlike kinase gene in Brassica oleracea. Plant Cell 9:49-60.

Peng, Y. L., Shirano, Y., Ohta, H., Hibino, T., Tanaka, K., and Shibata, D. 1994. A novel lipoxygenase from rice-primary structure and specific expression upon incompatible infection with rice blast fungus. J. Biol. Chem. 269:3755-3761.

Pieterse, C. M. J., and Van Loon, L. C. 1999. Salicylic acid-independent plant defense pathways. Trends Plant Sci. 4:52-58.

Pieterse, C. M. J., van Wees, S. C. M., Hoffland, E., van Pelt, J. A., and van Loon, L. C. 1996. Systemic resistance in Arabidopsis induced by biocontrol bacteria is independent of salicylic acid accumulation and pathogenesis-related gene expression. Plant Cell 8:1225-1237.

Reymond, P., Weber, H., Damond, M., and Farmer, E. E. 2000. Differential gene expression in response to mechanical wounding and insect feeding in Arabidopsis. Plant Cell 12:707-719.

Reymond, P., Bodenhausen, N., Van Poecke, R. M. P., Krishnamurthy, V., Dicke, M., and Farmer, E. E. 2004. A conserved transcript pattern in response to a specialist and a generalist herbivore. Plant Cell 16:3132-3147.

Root, R. B. 1973. Organization of a plant-arthropod association in simple and diverse habitats: The fauna of collards (Brassica oleracea). Ecol. Monogr. 43:95-124.

Rostas, M., and Hilker, M. 2002a. Asymmetric plant-mediated crosseffects between a herbivorous insect and a phytopathogenic fungus. Agric. For. Entomol. 4:223-231.

Rostas, M., and Hilker, M. 2002b. Feeding damage by larvae of the mustard leaf beetle deters conspecific females from oviposition and feeding. Entomol. Exp. Appl. 103:267-277.

Rostas, M., and Hilker, M. 2003. Indirect interactions between a phytopathogenic and an entomopathogenic fungus. Naturwissenschaften 90:6367.

Royo, J., Vancanneyt, G., Perez, A. G., Sanz, C., Stormann, K., Rosahl, S., and SanchezSerrano, J. J. 1996. Characterization of three potato lipoxygenases with distinct enzymatic activities and different organ-specific and wound-regulated expression patterns. J. Biol. Chem. 271:2101221019.

Royo, J., Leon, J., Vancanneyt, G., Albar, J. P., Rosahl, S., Ortego, F., Castanera, P., and Sanchez-Serrano, J. J. 1999. Antisense-mediated depletion of a potato lipoxygenase reduces wound induction of proteinase inhibitors and increases weight gain of insect pests. Proc. Natl. Acad. Sci. U.S.A. 96:1146-1151.

Ryals, J., Lawton, K. A., Delaney, T. P., Friedrich, L., Kessmann, H., Neuenschwander, U., Uknes, S., Vernooij, B., and Weymann, K. 1995. Signal transduction in systemic acquired resistance. Proc. Natl. Acad. Sci. U.S.A. 92:4202-4205.

Ryang, S. H., Chung, S. Y., Lee, S. H., Cha, J. S., Kim, H. Y., and Cho, T. J. 2002. Isolation of pathogen-induced Chinese cabbage genes by subtractive hybridization employing selective adaptor ligation. Biochem. Biophys. Res. Commun. 299:352-359.

Scascighini, N., Mattiacci, L., D’Alessandro, M., Hern, A., Rott, A. S., and Dorn, S. 2005. New insights in analysing parasitoid attracting synomones: Early volatile emission and use of stir bar sorptive extraction. Chemoecology 15:97-104.

Schoonhoven, L. M., van Loon, J. J. A., and Dicke, M. 2005. Insect-Plant Biology. Oxford University Press, Oxford.

Shiojiri, K., Takabayashi, J., Yano, S., and Takafuji, A. 2002. Oviposition preferences of herbivores are affected by tritrophic interaction webs. Ecol. Lett. 5:186-192.

Steinberg, S., Dicke, M., Vet, L. E. M., and Wanningen, R. 1992. Response of the braconid parasitoid Cotesia (=Apanteles) glomerata to volatile infochemicals: Effects of bioassay set-up, parasitoid age and experience and barometric flux. Entomol. Exp. Appl. 63:163-175.

Stotz, H. U., Koch, T., Biedermann, A., Weniger, K., Boland, W., and Mitchell-Olds, T. 2002. Evidence for regulation of resistance in Arabidopsis to Egyptian cotton worm by salicylic and jasmonic acid signaling pathways. Planta 214:648-652.

Stout, M. J., Thaler, J. S., and Thomma, B. P. H. I. 2006. Plant-mediated interactions between pathogenic microorganisms and herbivorous arthropods. Annu. Rev. Entomol. 51:663-689.

Terp, N., Gobel, C., Brandt, A., and Feussner, I. 2006. Lipoxygenases during Brassica napus seed germination. Phytochemistry 67:2030-2040.

Thaler, J. S., Karban, R., Ullman, D. E., Boege, K., and Bostock, R. M. 2002. Cross-talk between jasmonate and salicylate plant defense pathways: Effects on several plant parasites. Oecologia 131:227-235.

van Dam, N. M., and Raaijmakers, C. E. 2006. Local and systemic induced responses to cabbage root fly larvae (Delia radicum) in Brassica nigra and B. oleracea. Chemoecology 16:17-24.

van Dam, N. M., Witjes, L., and Svatos, A. 2004. Interactions between aboveground and belowground induction of glucosinolates in two wild Brassica species. New Phytol. 161:801-810.

Van Poecke, R. M. P., and Dicke, M. 2002. Induced parasitoid attraction by Arabidopsis thaliana: Involvement of the octadecanoid and the salicylic acid pathway. J. Exp. Bot. 53:1793-1799.

Van Poecke, R. M. P., and Dicke, M. 2004. Indirect defense of plants against herbivores: Using Arabidopsis thaliana as a model plant. Plant Biol. 6:387-401.

Van Poecke, R. M. P., Posthumus, M. A., and Dicke, M. 2001. Herbivoreinduced volatile production by Arabidopsis thaliana leads to attraction of the parasitoid Cotesia rubecula: Chemical, behavioral, and gene-expression analysis. J. Chem. Ecol. 27:1911-1928.

Vuorinen, T., Nerg, A. M., Ibrahim, M. A., Reddy, G. V. P., and Holopainen, J. K. 2004. Emission of Plutella xylostella-induced compounds from cabbages grown at elevated $\mathrm{CO}_{2}$ and orientation behavior of the natural enemies. Plant Physiol. 135:1984-1992.

Walling, L. L. 2000. The myriad plant responses to herbivores. J. Plant Growth Regul. 19:195-216.

Wasternack, C., Stenzel, I., Hause, B., Hause, G., Kutter, C., Maucher, H., Neumerkel, J., Feussner, I., and Miersch, O. 2006. The wound response in tomato - Role of jasmonic acid. J. Plant Physiol. 163:297-306.

Whalen, M. C., Innes, R. W., Bent, A. F., and Staskawicz, B. J. 1991. Identification of Pseudomonas syringae pathogens of Arabidopsis and a bacterial locus determining avirulence on both Arabidopsis and soybean. Plant Cell 3:49-59.

Wittstock, U., Agerbirk, N., Stauber, E. J., Olsen, C. E., Hippler, M., Mitchell-Olds, T., Gershenson, J., and Vogel, H. 2004. Successful herbivore attack due to metabolic diversion of a plant chemical defense. Proc. Natl. Acad. Sci. U.S.A. 101:4859-4864.

Yenofsky, R. L., Fine, M., and Liu, C. 1988. Isolation and characterization of a soybean (Glycine max) lipoxygenase-3 gene. Mol. Gen. Genet. 211:215-222.

Zheng, S. J., Henken, B., de Maagd, R. A., Purwito, A., Krens, F. A., and Kik, C. 2005. Two different Bacillus thuringiensis toxin genes confer resistance to beet armyworm (Spodoptera exigua Hubner) in transgenic Bt-shallots (Allium cepa L.). Transgenic Res. 14:261-272.

\section{AUTHOR-RECOMMENDED INTERNET RECOURCES}

CAP3 Sequence Assembly Program website: pbil.univ-lyon1.fr/cap3.php University of Glasgow, Institute of Biomedicaland Life Sciences Treeview webpage: taxonomy.zoology.gla.ac.uk/rod/treeview.html

PSORT WWW server: psort.nibb.ac.jp 